\title{
Previous Crop and Cultivar Effects on Methane Emissions from Drill-Seeded, Delayed-Flood Rice Grown on a Clay Soil
}

\author{
Alden D. Smartt, ${ }^{1}$ Kristofor R. Brye, ${ }^{1}$ Christopher W. Rogers, ${ }^{2}$ Richard J. Norman, \\ Edward E. Gbur, ${ }^{3}$ Jarrod T. Hardke, ${ }^{4}$ and Trenton L. Roberts ${ }^{1}$ \\ ${ }^{1}$ Department of Crop, Soil, and Environmental Sciences, University of Arkansas, Fayetteville, AR 72701, USA \\ ${ }^{2}$ Department of Plant, Soil, and Entomological Sciences, Aberdeen Research and Extension Center, University of Idaho, \\ Aberdeen, ID 83210, USA \\ ${ }^{3}$ Agricultural Statistics Laboratory, University of Arkansas, Fayetteville, AR 72701, USA \\ ${ }^{4}$ Department of Crop, Soil, and Environmental Sciences, Rice Research and Extension Center, University of Arkansas, \\ Stuttgart, AR 72160, USA \\ Correspondence should be addressed to Kristofor R. Brye; kbrye@uark.edu
}

Received 11 November 2015; Accepted 16 February 2016

Academic Editor: Amaresh K. Nayak

Copyright (C) 2016 Alden D. Smartt et al. This is an open access article distributed under the Creative Commons Attribution License, which permits unrestricted use, distribution, and reproduction in any medium, provided the original work is properly cited.

\begin{abstract}
Due to anaerobic conditions that develop in soils under flooded-rice (Oryza sativa L.) production, along with the global extent of rice production, it is estimated that rice cultivation is responsible for $11 \%$ of global anthropogenic methane $\left(\mathrm{CH}_{4}\right)$ emissions. In order to adequately estimate $\mathrm{CH}_{4}$ emissions, it is important to include data representing the range of environmental, climatic, and cultural factors occurring in rice production, particularly from Arkansas, the leading rice-producing state in the US, and from clay soils. The objective of this study was to determine the effects of previous crop (i.e., rice or soybean (Glycine max L.)) and cultivar (i.e., Cheniere (pure-line, semidwarf), CLXL745 (hybrid), and Taggart (pure-line, standard-stature)) on $\mathrm{CH}_{4}$ fluxes and emissions from rice grown on a Sharkey clay (very-fine, smectitic, thermic Chromic Epiaquerts) in eastern Arkansas. Rice following rice as a previous crop generally had greater $(p<0.01)$ fluxes than rice following soybean, resulting in growing season emissions $(p<0.01)$ of 19.6 and $7.0 \mathrm{~kg} \mathrm{CH}_{4}-\mathrm{Cha}^{-1}$, respectively. The resulting emissions from CLXL745 $\left(10.2 \mathrm{~kg} \mathrm{CH}_{4}-\mathrm{Cha}^{-1}\right)$ were less $(p=0.03)$ than those from Cheniere or Taggart (15.5 and $14.2 \mathrm{~kg} \mathrm{CH}_{4}-\mathrm{Cha}^{-1}$, resp.), which did not differ. Results of this study indicate that common Arkansas practices, such as growing rice in rotation with soybean and planting hybrid cultivars, may result in reduced $\mathrm{CH}_{4}$ emissions relative to continuous rice rotations and pure-line cultivars, respectively.
\end{abstract}

\section{Introduction}

Agricultural practices around the globe are estimated to account for nearly half of anthropogenic methane $\left(\mathrm{CH}_{4}\right)$ emissions, and rice (Oryza sativa L.) cultivation is one of the leading agricultural sources of $\mathrm{CH}_{4}$, accounting for $22 \%$ of global anthropogenic agricultural emissions, second only to enteric fermentation $[1,2]$. Rice is the only major row crop grown under flooded-soil conditions and the anoxic environment leads to the production and emission of $\mathrm{CH}_{4}$, a greenhouse gas with a global warming potential (GWP) 25 times stronger than carbon dioxide $\left(\mathrm{CO}_{2}\right)$ [3]. The GWP of rice cultivation has been estimated to be 2.7 and 5.7 times greater than that of maize (Zea mays L.) and wheat (Triticum aestivum $\mathrm{L}$.) systems, respectively, with $\mathrm{CH}_{4}$ specifically contributing more than $90 \%$ to the GWP of rice systems $[4,5]$.

Methane production occurs in anaerobic soils as a specific group of Archaea, collectively known as methanogens, utilize acetate or hydrogen gas and $\mathrm{CO}_{2}$, which are formed as fermentation products of a greater consortium of anaerobic bacteria, as substrates for methanogenesis [6]. A portion of the $\mathrm{CH}_{4}$ produced during methanogenesis, however, is oxidized by a group of aerobic bacteria, known as methanotrophs, as $\mathrm{CH}_{4}$ moves through oxidized portions of soil surrounding rice roots $[7,8]$ and near the soil surface $[9,10]$. Studies have shown that up to $90 \%$ of $\mathrm{CH}_{4}$ produced in the soil of rice systems is oxidized prior to entering the atmosphere, greatly 
reducing the proportion of produced $\mathrm{CH}_{4}$ that is released from the soil $[9,11-15]$.

Studies have indicated that the majority of $\mathrm{CH}_{4}$ released from rice fields occurs through the aerenchyma tissues of rice plants, with this plant-mediated transport mechanism accounting for about $90 \%$ of emissions, compared to around 8 and $2 \%$ of emissions from ebullition and diffusion through the floodwater, respectively $[9,12,15,16]$. Furthermore, several studies have identified a positive correlation between $\mathrm{CH}_{4}$ emissions and both aboveground and belowground dry matter accumulation [17-20], which may result from an increase in available substrate as root exudates have been correlated to biomass [21] or due to differences in methane transport capacity (MTC) between cultivars. ButterbachBahl et al. [15], for example, attributed a 24 to $31 \%$ difference in emissions between two pure-line cultivars to differences in MTC, as no differences were observed between $\mathrm{CH}_{4}$ production and oxidation. Several studies have observed increased emissions from standard-stature relative to semidwarf cultivars, which is consistent with the positive effect of biomass on $\mathrm{CH}_{4}$ emissions [22-24]. Cultivar differences extend beyond the impact of biomass on emissions, however, as $\mathrm{Ma}$ et al. [25] observed a reduction in emissions and soil $\mathrm{CH}_{4}$ concentration accompanied by a $67 \%$ increase in $\mathrm{CH}_{4}$ oxidation from a hybrid cultivar relative to pure-line Indica and Japonica cultivars. Additional studies have observed a similar reduction in emissions from hybrid cultivars [2628]. With the exception of plant height through its general relationship to aboveground biomass, few other plant morphological characteristics, such as leaf area or photosynthetic activity, have been shown to be related to $\mathrm{CH}_{4}$ emissions.

While the study of Rogers et al. [26] is the only known study that has directly compared emissions from rice following rice or soybean as previous crops and that observed a $31 \%$ reduction in emissions following soybean compared to following rice, several other studies have reported reductions in emissions when previous crop residue was burned [29-31] or when growing rice following a tillage-suppressed fallow period [17, 32]. Furthermore, it has been suggested that promoting aerobic decomposition of residues or growing rice in rotation with upland crops may provide a means of $\mathrm{CH}_{4}$ mitigation as composted residues reportedly resulted in a sixfold decrease in available substrate for methanogenesis relative to rice straw or green manure $[33,34]$. Although it has not been studied greatly, the impact of residue management and rotation with upland crops, such as soybean, has shown potential for mitigation of $\mathrm{CH}_{4}$ emissions.

Currently, $\mathrm{CH}_{4}$ emissions budgets in the US are calculated by summing contributions from identifiable homogeneous areas, such that average measured fluxes of representative factors are used in estimates on a regional or national basis $[35,36]$. Based on limited studies with emissions ranging from 46 to $375 \mathrm{~kg} \mathrm{CH}_{4}-\mathrm{C} \mathrm{ha}^{-1}$ season ${ }^{-1}$, the United States Environmental Protection Agency (USEPA) is currently using one emission factor $\left(178 \mathrm{~kg} \mathrm{CH}_{4}-\mathrm{Cha}^{-1}\right.$ season $\left.^{-1}\right)$ for all non-California primary rice crops, while separate factors are used when ratooning or for winter-flooded and nonwinter-flooded rice in California [37]. As more data become available, $\mathrm{CH}_{4}$ budgets and models can be further refined to account for factors such as soil texture, previous crop, and cultivar. This is particularly important for Arkansas, which accounts for nearly $50 \%$ of the total US rice production and contains a large portion of production following soybean (71\%) and planted with hybrid cultivars $(>40 \%)$, both of which have been shown to reduce emissions [26] and could be used to create more accurate and potentially lower $\mathrm{CH}_{4}$ emission factors for midsouthern US rice production [38].

The impact of rice cultivation on greenhouse gas emissions coupled with the intense management involved in rice production allows for potential mitigation strategies based on various practices that are known to reduce $\mathrm{CH}_{4}$ emissions, such as increasing the use of high-yielding cultivars that have shown potential for reduced emissions. Consequently, it is necessary to study the impacts of various practices on $\mathrm{CH}_{4}$ emissions in a wide array of soils and climates in order to adequately understand the extent of the problem and to direct management practices toward mitigation of the greenhouse gas, while maintaining high yields and profitability.

While research on $\mathrm{CH}_{4}$ emissions from rice has recently been conducted in Arkansas [26-28, 39-44], no study has examined the influence of previous crop and cultivar selection on direct-seeded, delayed-flood rice production on a clay soil in the midsouthern US. Direct measurements of $\mathrm{CH}_{4}$ fluxes and emissions from field studies are necessary to further refine the USEPA emission factors. Therefore, the objective of this study was to assess the impact of previous crop (i.e., rice and soybean) and cultivar (i.e., standardstature, semidwarf, and hybrid) on $\mathrm{CH}_{4}$ fluxes and seasonlong emissions from drill-seeded, delayed-flood rice produced on a clay soil in eastern Arkansas. It was hypothesized that $\mathrm{CH}_{4}$ fluxes and emissions would be greater when following rice as a previous crop due to the more recalcitrant nature of the rice straw residue, compared to the more labile soybean residue. It was also hypothesized that the hybrid cultivar would result in lower $\mathrm{CH}_{4}$ fluxes and emissions than the two pure-line cultivars due to increased methanotrophic activity and $\mathrm{CH}_{4}$ oxidation that has been observed in hybrid cultivars [25]. Furthermore, it was hypothesized that $\mathrm{CH}_{4}$ fluxes and emissions would be less from the semidwarf cultivar than those from the standard-stature cultivar as was observed by Lindau et al. [22].

\section{Materials and Methods}

2.1. Site Description. Research was conducted during the 2013 growing season at the University of Arkansas System Division of Agriculture Northeast Research and Extension Center in Keiser, Mississippi County, Arkansas $\left(35^{\circ} 40^{\prime} \mathrm{N} 90^{\circ} 05^{\prime} \mathrm{W}\right)$. Field plots were located on a Sharkey clay (very-fine, smectitic, thermic Chromic Epiaquerts), which makes up 31\% of the Mississippi County soil survey area [45]. The study site is located within the Southern Mississippi River Alluvium Major Land Resource Area (MLRA 131A), which is located along the Mississippi River from the southern tip of Illinois to the Gulf Coast and is composed of approximately $70 \%$ cropland [46]. The location of the study has been cropped in a rice-soybean rotation for more than 25 years and crop 
residues are typically incorporated in the fall by disking to a depth of $15 \mathrm{~cm}$. Mean annual precipitation at this site is $126 \mathrm{~cm}$, ranging from an average of $6.8 \mathrm{~cm}$ in August to an average of $14.1 \mathrm{~cm}$ in May [47]. The mean annual air temperature is $15.5^{\circ} \mathrm{C}$, while the mean minimum and maximum temperatures occur in January $\left(-2.4^{\circ} \mathrm{C}\right)$ and July $\left(33.3^{\circ} \mathrm{C}\right)$, respectively [47].

2.2. Treatments and Experimental Design. The purpose of this study was to examine the impacts of previous crop (rice or soybean) and rice cultivar (standard-stature, semidwarf, or hybrid) on $\mathrm{CH}_{4}$ fluxes and season-long emissions from rice grown on a clay soil in Arkansas. Cultivars were selected in an attempt to represent rice commonly produced in Arkansas with various growth characteristics and breeding lines. The cultivar "Cheniere," developed at Louisiana State University [48], was selected as a pure-line, semidwarf cultivar. Cheniere is an early season, long-grain rice cultivar with an average height of $97 \mathrm{~cm}$ and average grain yield of $8.9 \mathrm{Mg} \mathrm{ha}^{-1}$ based on Arkansas Rice Performance trials [49]. The standardstature, pure-line cultivar "Taggart," developed at the University of Arkansas [50], was also selected due to its high yield potential. Taggart is a midseason, long-grain cultivar with an average grain yield of $10.0 \mathrm{Mg} \mathrm{ha}^{-1}$ and an average height of $117 \mathrm{~cm}$ [49]. The final cultivar selected for use in this study was the hybrid "CLXL745" (RiceTec, Inc., Houston, TX), which is a very early season, long-grain cultivar averaging $114 \mathrm{~cm}$ in height and achieving an average yield of $10.1 \mathrm{Mg} \mathrm{ha}^{-1}$ in Arkansas [49]. The hybrid cultivar CLXL745 was the most popular cultivar in Arkansas in 2012 and 2013, accounting for 28 and $22 \%$ of total production, respectively, in those years [38].

Research plots were $1.6 \mathrm{~m}$ wide by $5 \mathrm{~m}$ long and arranged in a split-plot design. Previous crop was the whole-plot factor, which was arranged as a randomized complete block with four replicates of each previous crop. The split-plot factor was rice cultivar and each of the three cultivars was randomly located within each of the previous crop, whole-plot units. Therefore, there were a total of 12 field plots per previous crop. Sample date was treated as a repeated measure in analyzing $\mathrm{CH}_{4}$ flux data.

2.3. Plot Management. Previous crop residues, which were left standing in the field following harvest, were incorporated one week prior to planting by disking to a depth of $15 \mathrm{~cm}$. Research plots were independently seeded on 28 May 2013 with nine rows of rice drill-seeded using $18 \mathrm{~cm}$ row spacing. The two pure-line cultivars, Cheniere and Taggart, and the hybrid, CLXL745, were seeded at rates of $112 \mathrm{~kg} \mathrm{ha}^{-1}$ and $34 \mathrm{~kg} \mathrm{ha}^{-1}$, respectively [51]. Levees were constructed following seeding and plots were irrigated with groundwater by flushing as necessary prior to permanent flood establishment, which occurred at the 4-6 leaf stages on 2 July 2013. According to University of Arkansas Cooperative Extension Service (UACES) guidelines [52], nitrogen $(\mathrm{N})$ was applied as urea $(46 \% \mathrm{~N})$ in a split application with the pure-line cultivars and hybrid cultivar receiving $151 \mathrm{~kg} \mathrm{~N} \mathrm{ha}^{-1}$ and $168 \mathrm{~kg} \mathrm{Nha}^{-1}$, respectively, one day prior to permanent flood establishment.
The second application of $\mathrm{N}$ occurred on 30 July 2013 at the beginning of internode elongation for the pure-line cultivars $\left(50 \mathrm{~kg} \mathrm{~N} \mathrm{ha}^{-1}\right)$ and at boot on 20 August 2013 for the hybrid cultivar $\left(33 \mathrm{~kg} \mathrm{~N} \mathrm{ha}^{-1}\right)$, amounting to a total of $201 \mathrm{~kg} \mathrm{~N} \mathrm{ha}^{-1}$ for all cultivars [53]. A floodwater depth of 5 to $10 \mathrm{~cm}$ was maintained until grain maturity on 23 September 2013, after which the floodwater was released and plots were allowed to dry prior to harvest, which occurred on 24 October 2013. Plots were scouted regularly and managed to remain insect- and weed-free during the growing season according to UACES guidelines $[54,55]$.

2.4. Soil Sampling and Analyses. Composite soil samples from six, $2 \mathrm{~cm}$ diameter soil cores were collected from the top $10 \mathrm{~cm}$ of each plot prior to flooding and $\mathrm{N}$ fertilization. Composite samples were then oven-dried at $70^{\circ} \mathrm{C}$ for 48 hours and passed through a $2 \mathrm{~mm}$ mesh screen sieve prior to subsamples being analyzed for Mehlich-3 extractable nutrients (i.e., P, $\mathrm{K}, \mathrm{Ca}, \mathrm{Mg}, \mathrm{Fe}, \mathrm{Mn}, \mathrm{Na}, \mathrm{S}, \mathrm{Cu}$, and $\mathrm{Zn}$ ) using inductively coupled plasma atomic emission spectroscopy (Spectro Analytical Instruments, Spectro Arcos ICP, Kleve, Germany) [56]. Additional dried, sieved subsamples were analyzed for total $\mathrm{N}$ (TN) and total C (TC) concentrations by high-temperature combustion using a VarioMax $\mathrm{CN}$ analyzer (Elementar Americas Inc., Mt. Laurel, NJ) [57] and analyzed for soil pH and electrical conductivity (EC) potentiometrically in a $1: 2$ $(\mathrm{m}: \mathrm{v})$ soil-to-water paste. Soil organic matter $(\mathrm{OM})$ concentration was determined by weight-loss-on-ignition [58].

Additional soil samples were collected from the top $10 \mathrm{~cm}$ in each plot prior to flooding using a slide hammer and $4.7 \mathrm{~cm}$ diameter core chamber with a beveled core tip. Bulk densities were determined after samples were oven-dried for 48 hours at $70^{\circ} \mathrm{C}$. Samples were then ground and sieved through a $2 \mathrm{~mm}$ mesh screen and analyzed for particle-size distribution using a modified 12-hour hydrometer method [59]. Bulk densities measured from each plot were then used in combination with measured TN, TC, and OM concentrations to determine total contents $\left(\mathrm{Mg} \mathrm{ha}^{-1}\right)$ of each in the top $10 \mathrm{~cm}$ of soil.

\subsection{Soil Redox Potential and Soil Temperature Monitoring.} Soil oxidation/reduction (redox) potential (Eh) was monitored throughout the flooded portion of the growing season using redox potential sensors (Sensorex, Model S650KDORP, Garden Grove, $\mathrm{CA}$ ) with $\mathrm{Ag} / \mathrm{AgCl}$ reference solution and a built-in reference electrode installed to a soil depth of $7.5 \mathrm{~cm}$ immediately prior to flooding. Additionally, chromelconstantan thermocouples were installed immediately prior to flooding to a soil depth of $7.5 \mathrm{~cm}$ in order to monitor soil temperature. Due to equipment limitations, soil Eh and temperature readings were only conducted in two of the four replicates of Cheniere and CLXL745 following each of the previous crops. Soil redox potential and temperature measurements were recorded at 4-hour intervals using a datalogger (CR 1000, Campbell Scientific Inc., Logan, UT) contained within an environmental enclosure. Soil redox potential measurements were corrected to the standard hydrogen electrode by adding $199 \mathrm{mV}$ [60]. 
2.6. Trace Gas Sampling and Analysis. Non-steady-state, enclosed headspace gas sampling chambers, similar to those used by Rogers et al. [26, 41, 42] and detailed by Livingston and Hutchinson [61], were used for collection of gas samples for $\mathrm{CH}_{4}$ analysis in this study. This methodology is common in measuring trace gas fluxes [62] and involves installing permanent base collars into the soil and using various sized chamber extensions along with a vented cap in order to accommodate increasing plant growth throughout the season. Base collars, chamber extensions, and chamber caps were constructed using schedule 40 polyvinyl chloride (PVC) pipe with an inside diameter of $30 \mathrm{~cm}$. Chamber base collars were cut to a length of $30 \mathrm{~cm}$ with one beveled edge for driving into the soil and four $12.5 \mathrm{~mm}$ holes placed $12 \mathrm{~cm}$ from the bottom to allow free movement of the floodwater. Chamber extensions cut to lengths of 40 and $60 \mathrm{~cm}$, in order to accommodate growing plants while minimizing chamber headspace volume, and $10 \mathrm{~cm}$ caps were covered with reflective aluminum tape (CS Hyde, Mylar metalized tape, Lake Villa, IL) in order to reduce temperature elevation during sampling. Cross sections of tire inner tubes cut to a width of $10 \mathrm{~cm}$ were adhered to the bottom of chamber extensions and caps in order to seal the separate pieces together. Chamber caps also included a $15 \mathrm{~cm}$ section of $4.5 \mathrm{~mm}$ ID copper tubing as a vent to maintain atmospheric pressure, sampling and thermometer ports of gray butyl-rubber septa (Voigt Global, part number 73828A-RB, Lawrence, KS), and a $2.5 \mathrm{~cm}$ diameter, battery operated ( 9 V) fan (Sunon Inc., MagLev, Brea, CA) to mix air within the chamber during $\mathrm{CH}_{4}$ sampling.

Boardwalks were established between plots prior to flooding in order to access chambers for sampling, while minimizing damage to plants and soil disturbance during sampling. Permanent base collars were installed within each plot to a depth of $11 \mathrm{~cm}$, where the four holes were just above the soil surface, and were situated to contain $40 \mathrm{~cm}$ of row length in order to duplicate the plant density of the plots. Plants were carefully bundled with plant tie wire in order to deploy chamber extensions during each sampling event without damaging plants and ties were removed immediately after extension placement as to not affect the plants during sampling. Headspace gas samples were collected weekly for the duration of flooding (i.e., 7, 14, 28, 36, 42, 49, 56, 63, 71, and 77 days after flooding (DAF)), with the exception of the period during the third week after flooding when poor weather conditions did not permit sampling, and every other day following flood release (i.e., 1, 3, 5, and 7 days after flood release (DAFR)).

Chamber headspace gas sampling occurred between 0800 and 1000 hours, similar to previous studies [20, 26, 41, 42, $44]$, in order to reduce excessive chamber heating during sampling, while sampling during a time of near-average soil temperatures. Samples were collected at 20-minute intervals (i.e., 0, 20, 40, and 60 minutes after sealing) using $20 \mathrm{~mL}$ B-D syringes (Becton Dickinson and Co., Franklin Lakes, NJ) and immediately transferred to evacuated $10 \mathrm{~mL}$, crimp-top glass vials (Agilent Technologies, part number 5182-0838, Santa Clara, CA). Chamber air temperature, $10 \mathrm{~cm}$ soil temperature, barometric pressure, and relative humidity were recorded throughout each sampling event and chamber volumes were calculated by measuring each chamber's height above the floodwater. Duplicate sets of $\mathrm{CH}_{4}$ standards (i.e., 1, 2, 5, 10, 20 , and $50 \mu \mathrm{L} \mathrm{L}^{-1}$ ) were collected in the field into evacuated glass vials and an additional set of laboratory standards was again collected immediately prior to sample analysis in order to ensure that sample integrity was maintained as samples were transported from the field to the laboratory.

Field samples, field standards, and laboratory standards were analyzed within 48 hours after each sampling event using an Agilent 6890-N gas chromatograph with a $30 \mathrm{~m}$ long by $0.53 \mathrm{~mm}$-diameter HP-Plot-Q capillary column (Agilent Technologies, Santa Clara, CA) and equipped with a flame-ionization detector (FID). Methane concentrations of field samples were determined based on calibration curves for each sampling event created from peak-area responses from known sample concentrations. Methane fluxes $\left(\mu \mathrm{L} \mathrm{CH}_{4} \mathrm{~m}^{-2} \mathrm{~min}^{-1}\right)$ were calculated for each chamber by using changes in headspace $\mathrm{CH}_{4}$ concentration $\left(\mu \mathrm{L} \mathrm{L}^{-1}\right.$, $y$-axis) regressed against time ( $\min , x$-axis) and multiplying the resulting best-fit line from that regression by chamber volume $(\mathrm{L})$ and dividing by chamber surface area $\left(\mathrm{m}^{2}\right)$ as outlined by Parkin and Venterea [62]. Fluxes were then converted to mass-based units (i.e., $\mathrm{mg} \mathrm{CH}_{4} \mathrm{~m}^{-2} \mathrm{~min}^{-1}$ ) using the Ideal Gas Law. Based on details by Parkin et al. [63], minimum detection limits (MDLs) for $\mathrm{CH}_{4}$ fluxes were calculated to be $0.03,0.08,0.11$, and $0.16 \mathrm{mg} \mathrm{CH}_{4}-\mathrm{C} \mathrm{m}^{-2} \mathrm{~h}^{-1}$ with the use of no extension or a 40,60 , or $100 \mathrm{~cm}$ extension, respectively. While MDLs were determined, measured fluxes below the MDLs were retained in calculating cumulative season-long emissions and for statistical analyses. Seasonlong total $\mathrm{CH}_{4}$ emissions were determined for each chamber by linear interpolation between flux measurement dates.

2.7. Plant Sampling and Analyses. Plant samples were collected at physiological maturity in order to determine any impact of previous crop and cultivar on aboveground dry matter accumulation as well as to compare aboveground dry matter from within and outside the chambers to investigate the impact of the chamber on plant growth. All biomass from within each chamber and a $1 \mathrm{~m}$ row of rice from adjacent to each chamber were cut at the soil surface, dried at $60^{\circ} \mathrm{C}$ until no further moisture loss occurred, and weighed in order to determine total aboveground dry matter accumulation. A $4 \mathrm{~m}$ length of the center five rows of each plot was harvested at physiological maturity (24 October 2013) using a plot-scale combine. Grain samples were then weighed and analyzed for moisture content so that final grain yields could be reported at $120 \mathrm{~g} \mathrm{~kg}^{-1}$ grain moisture content.

2.8. Statistical Analyses. Initial soil chemical and physical properties were analyzed by analysis of variance (ANOVA) in SAS 9.2 (SAS Institute, Inc., Cary, NC) using PROC Mixed based on a split-plot design (i.e., the whole-plot factor was previous crop and the split-plot factor was cultivar) in order to determine any differences in soil properties among treatment combinations. Similarly, grain yield was analyzed by ANOVA based on the split-plot design in order to determine the impact of previous crop and cultivar on grain yields. An additional ANOVA was performed based on 
a split-split-plot design (i.e., the whole-plot factor was previous crop, the first split-plot factor was cultivar, and the second split-plot factor was sampling location) in order to compare total aboveground dry matter accumulation as affected by sampling location (i.e., in-chamber or in-plot), previous crop, and cultivar.

Methane flux data showed no indication of a nonnormal distribution based on an inspection for normality using normal probability plots of the studentized residuals. Consequently, an ANOVA was performed based on a splitplot, repeated measures design (i.e., previous crop was the whole-plot factor, cultivar was the split-plot factor, and time was a repeated measure) to evaluate the impact of previous crop, cultivar, and their interaction on $\mathrm{CH}_{4}$ fluxes over time. Flux data were analyzed separately for the duration of flooding and following flood release due to differences in $\mathrm{CH}_{4}$ transport mechanisms and sampling intervals. Seasonal total $\mathrm{CH}_{4}$ emissions, calculated based on mass-per-area (areascaled) and mass-per-grain-yield (yield-scaled), as well as post-flood-release emissions, on an area-scaled basis and as a percentage of total seasonal emissions, were analyzed by ANOVA based on a split-plot design (i.e., previous crop was the whole-plot factor and cultivar was the split-plot factor). When appropriate, means were separated at the 0.05 level using the Fisher protected least significant difference (LSD). Linear correlation and regression analyses were performed using Minitab (version 16, Minitab, Inc., State College, PA) in order to evaluate the relationships between sand and clay contents and growing season emissions and aboveground dry matter and growing season emissions.

\section{Results and Discussion}

3.1. Initial Soil Physical and Chemical Properties. Several initial soil physical and chemical properties in the top $10 \mathrm{~cm}$ differed based on previous crop $(p<0.05)$; however, initial soil properties did not differ based on cultivar (Table 1). The most notable differences were in soil particle-size distribution, where sand content was $4 \%$ greater and clay content was $4.7 \%$ less in the treatments where rice was the previous crop compared to soybean as a previous crop. The difference in particle-size distribution was likely due to natural spatial variability within the alluvial study site. While these differences likely had no agronomic significance, several studies have observed an inverse correlation between soil clay content and $\mathrm{CH}_{4}$ emissions as well as a positive correlation between soil sand content and $\mathrm{CH}_{4}$ emissions [32, 64, 65].

In addition to having a slightly greater clay content, the treatment combinations following soybean as a previous crop had greater extractable calcium (Ca), magnesium $(\mathrm{Mg})$, and zinc $(\mathrm{Zn})$, as well as a greater OM concentration (Table 1$)$. The differences in $\mathrm{Ca}, \mathrm{Mg}$, and $\mathrm{Zn}$ concentrations, however, were minor in comparison to the relatively high concentrations of these nutrients in both previous crop treatments and likely posed no practical significance in this study. There were no differences in $\mathrm{OM}, \mathrm{TN}$, or TC contents among treatments (Table 1), indicating that available substrate for methanogenesis was similar among all treatment combinations prior to flooding. Extractable soil phosphorus (P) was
TABLE 1: Mean soil properties ( $N=12$ for each previous crop) prior to flood establishment from Sharkey clay during the 2013 growing season at the University of Arkansas Northeast Research and Extension Center in Keiser, Arkansas.

\begin{tabular}{|c|c|c|}
\hline \multirow{2}{*}{ Soil property } & \multicolumn{2}{|c|}{ Previous crop } \\
\hline & Rice & Soybean \\
\hline $\mathrm{pH}$ & $7.06^{\mathrm{a} \dagger}$ & $7.13^{\mathrm{a}}$ \\
\hline Electrical conductivity $\left(\mathrm{dS} \mathrm{m}^{-1}\right.$ ) & $0.216^{\mathrm{a}}$ & $0.202^{\mathrm{a}}$ \\
\hline Sand $\left(\mathrm{gg}^{-1}\right)$ & $0.14^{\mathrm{a}}$ & $0.10^{\mathrm{b}}$ \\
\hline Silt $\left(\mathrm{g} \mathrm{g}^{-1}\right)$ & $0.34^{\mathrm{a}}$ & $0.33^{\mathrm{a}}$ \\
\hline Clay $\left(\mathrm{gg}^{-1}\right)$ & $0.52^{\mathrm{b}}$ & $0.57^{\mathrm{a}}$ \\
\hline Bulk density $\left(\mathrm{g} \mathrm{cm}^{-3}\right)$ & $1.17^{\mathrm{a}}$ & $1.09^{\mathrm{a}}$ \\
\hline \multicolumn{3}{|c|}{ Mehlich-3 extractable nutrients $\left(\mathrm{mg} \mathrm{kg}^{-1}\right)$} \\
\hline $\mathrm{P}$ & $55.9^{\mathrm{a}}$ & $46.3^{\mathrm{b}}$ \\
\hline $\mathrm{K}$ & $387^{\mathrm{a}}$ & $390^{\mathrm{a}}$ \\
\hline $\mathrm{Ca}$ & $4147^{\mathrm{b}}$ & $4570^{\mathrm{a}}$ \\
\hline $\mathrm{Mg}$ & $867^{\mathrm{b}}$ & $919^{\mathrm{a}}$ \\
\hline $\mathrm{Fe}$ & $467^{\mathrm{a}}$ & $445^{\mathrm{a}}$ \\
\hline Mn & $51.1^{\mathrm{a}}$ & $53.9^{\mathrm{a}}$ \\
\hline $\mathrm{Na}$ & $54.5^{\mathrm{a}}$ & $59.3^{\mathrm{a}}$ \\
\hline S & $17.6^{\mathrm{a}}$ & $12.3^{\mathrm{a}}$ \\
\hline $\mathrm{Cu}$ & $4.0^{\mathrm{a}}$ & $4.7^{\mathrm{a}}$ \\
\hline $\mathrm{Zn}$ & $3.4^{\mathrm{b}}$ & $3.5^{\mathrm{a}}$ \\
\hline Organic matter $\left(\mathrm{g} \mathrm{kg}^{-1}\right)$ & $37.7^{\mathrm{b}}$ & $39.6^{\mathrm{a}}$ \\
\hline Organic matter $\left(\mathrm{Mg} \mathrm{ha}^{-1}\right)$ & $44.0^{\mathrm{a}}$ & $43.1^{\mathrm{a}}$ \\
\hline Total $\mathrm{N}\left(\mathrm{g} \mathrm{kg}^{-1}\right)$ & $1.4^{\mathrm{a}}$ & $1.4^{\mathrm{a}}$ \\
\hline Total N $\left(\mathrm{Mg} \mathrm{ha}^{-1}\right)$ & $1.6^{\mathrm{a}}$ & $1.5^{\mathrm{a}}$ \\
\hline Total C $\left(\mathrm{g} \mathrm{kg}^{-1}\right)$ & $15.0^{\mathrm{a}}$ & $14.8^{\mathrm{a}}$ \\
\hline Total C $\left(\mathrm{Mg} \mathrm{ha}^{-1}\right)$ & $17.4^{\mathrm{a}}$ & $16.1^{\mathrm{a}}$ \\
\hline $\mathrm{C}: \mathrm{N}$ ratio & $10.8^{\mathrm{a}}$ & $10.5^{\mathrm{a}}$ \\
\hline
\end{tabular}

${ }^{\dagger}$ Values in the same row followed by different letters are significantly different $(p<0.05)$.

greater $(p<0.05)$ following rice as a previous crop and was within the above-optimum level $\left(\geq 51 \mathrm{mg} \mathrm{kg}^{-1}\right)$, while the $\mathrm{P}$ concentration following soybean was within the optimum level ( 36 to $50 \mathrm{mg} \mathrm{kg}^{-1}$ ), indicating adequate native soil $\mathrm{P}$ in both previous crop treatments based on UACES recommendations [53]. Extractable soil potassium (K) was unaffected by previous crop and was within the above-optimum level $\left(\geq 174 \mathrm{mg} \mathrm{kg}^{-1}\right)$. Extractable soil zinc ( $\mathrm{Zn}$ ) was also unaffected by previous crop and was within the medium level (2.6 to $4.0 \mathrm{mg} \mathrm{kg}^{-1}$ ) recommended for rice, indicating adequate levels of both $\mathrm{K}$ and $\mathrm{Zn}$ for rice production [53].

3.2. Methane Fluxes from Flooding to Flood Release. Methane fluxes measured during the flooded portion of the 2013 growing season differed between previous crops over time $(p<$ $0.001)$ and differed among cultivars over time $(p<0.001)$ (Table 2). Averaged across cultivar, $\mathrm{CH}_{4}$ fluxes did not differ among previous crops on the first two or the final sampling dates (i.e., 7, 14, and 77 DAF), while fluxes were greater when the previous crop was rice for the remainder of the sampling dates (Figure 1). Both previous crop treatments exhibited the same trend, where fluxes generally increased from less 
TABLE 2: Analysis of variance summary of the effects of previous crop, cultivar, time, and their interaction on methane $\left(\mathrm{CH}_{4}\right)$ fluxes from flooding to flood release and following flood release from a clay soil during the 2013 growing season at the Northeast Research and Extension Center in Keiser, Arkansas.

\begin{tabular}{lcc}
\hline & \multicolumn{2}{c}{ Measurement period } \\
Source of variation & $\begin{array}{c}\text { Flooding to } \\
\text { flood release }\end{array}$ & $\begin{array}{c}\text { Post-flood } \\
\text { release }\end{array}$ \\
\hline Previous crop & 0.004 & 0.131 \\
Cultivar & 0.027 & 0.962 \\
$\quad$ Previous crop $\times$ cultivar & 0.099 & 0.770 \\
Time & $<0.001$ & 0.002 \\
Previous crop $\times$ time & $<0.001$ & 0.369 \\
Cultivar $\times$ time & $<0.001$ & 0.270 \\
$\quad$ Previous crop $\times$ cultivar $\times$ time & 0.639 & 0.537 \\
\hline
\end{tabular}

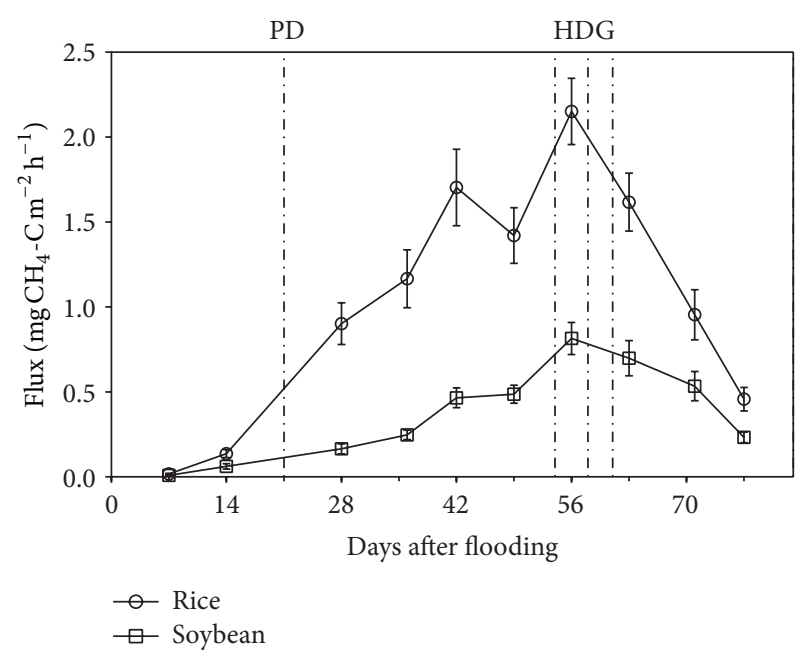

FIGURE 1: Methane fluxes over time throughout the flooded portion of the 2013 growing season from previous crop treatments averaged across cultivar at the Northeast Research and Extension Center in Keiser, Arkansas. The vertical dashed lines represent panicle differentiation (PD) and 50\% heading (HDG) dates for CLXL745, Cheniere, and Taggart at 54,58, and 61 days after flooding, respectively. Flood release occurred in 83 days after flooding. Least significant difference for the same previous crop treatment $=$ $0.197 \mathrm{mg} \mathrm{CH}_{4}-\mathrm{C} \mathrm{m}^{-2} \mathrm{hr}^{-1}$ and for different previous crop treatment $=0.309 \mathrm{mg} \mathrm{CH}_{4}-\mathrm{C} \mathrm{m}^{-2} \mathrm{hr}^{-1}$. Error bars indicate standard errors for the treatment means $(N=12)$.

than $0.02 \mathrm{mg} \mathrm{CH}_{4}-\mathrm{C} \mathrm{m}^{-2} \mathrm{~h}^{-1}$ at $7 \mathrm{DAF}$ to peaks of 2.15 and $0.81 \mathrm{mg} \mathrm{CH}_{4}-\mathrm{C} \mathrm{m}^{-2} \mathrm{~h}^{-1}$ that occurred at $56 \mathrm{DAF}$ in the rice following rice and rice following soybean treatments, respectively. After peak $\mathrm{CH}_{4}$ fluxes occurred near the time of $50 \%$ heading, fluxes decreased over time to 0.46 and $0.23 \mathrm{mg} \mathrm{CH}_{4}^{-}$ $\mathrm{C} \mathrm{m}^{-2} \mathrm{~h}^{-1}$ following rice and soybean as previous crops, respectively, at $77 \mathrm{DAF}$, the final sampling date of the flooded portion of the season. In the only other known study to have directly compared $\mathrm{CH}_{4}$ fluxes from rice and soybean as previous crops, Rogers et al. [26] observed similar results on

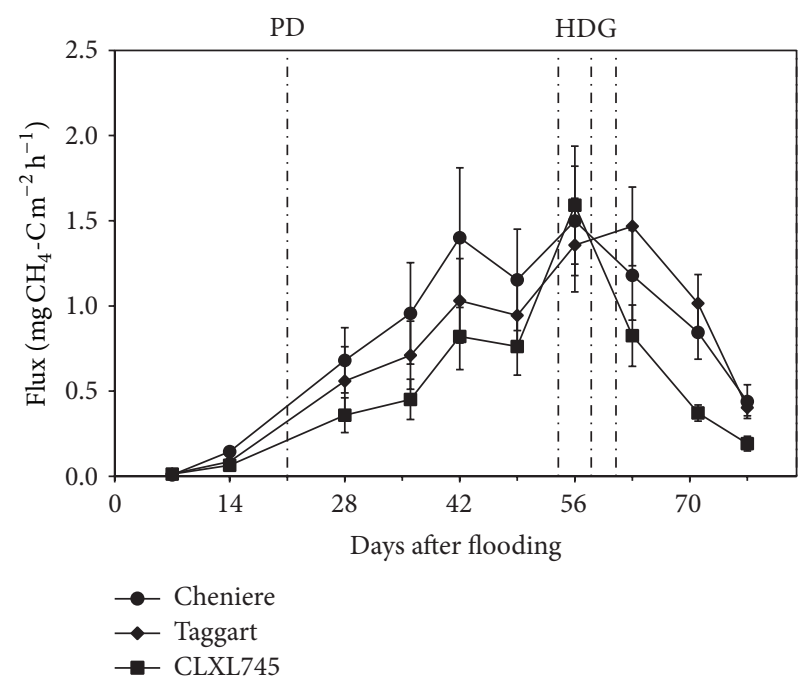

FIGURE 2: Methane fluxes over time throughout the flooded portion of the 2013 growing season from CLXL745, Cheniere, and Taggart averaged across previous crop treatment at the Northeast Research and Extension Center in Keiser, Arkansas. The vertical dashed lines represent panicle differentiation (PD) and 50\% heading (HDG) dates for CLXL745, Cheniere, and Taggart at 54, 58, and 61 days after flooding, respectively. Flood release occurred in 83 days after flooding. Least significant difference for the same cultivar $=0.241 \mathrm{mg} \mathrm{CH}_{4}-\mathrm{C} \mathrm{m}^{-2} \mathrm{hr}^{-1}$ and for different cultivars = $0.307 \mathrm{mg} \mathrm{CH}_{4}-\mathrm{C} \mathrm{m}^{-2} \mathrm{hr}^{-1}$. Error bars indicate standard errors for the treatment means $(N=8)$.

a silt-loam soil, where fluxes were consistently lower when soybean was the previous crop and average peak fluxes of approximately 16.8 and $12.8 \mathrm{mg} \mathrm{CH}_{4}-\mathrm{C} \mathrm{m}^{-2} \mathrm{~h}^{-1}$ following rice and soybean, respectively, occurred near $50 \%$ heading.

Averaged across previous crop, $\mathrm{CH}_{4}$ fluxes did not differ among cultivars on the first two sample dates (i.e., 7 and 14 DAF), where all fluxes were less than $0.15 \mathrm{mg} \mathrm{CH}_{4}-\mathrm{C} \mathrm{m}^{-2} \mathrm{~h}^{-1}$, or on the final sample date, where all fluxes were less than $0.44 \mathrm{mg} \mathrm{CH}_{4}-\mathrm{C} \mathrm{m}^{-2} \mathrm{~h}^{-1}$ (i.e., $77 \mathrm{DAF}$ ) (Figure 2). All three cultivars exhibited a general increase in $\mathrm{CH}_{4}$ fluxes up to a peak of approximately $1.5 \mathrm{mg} \mathrm{CH}_{4}-\mathrm{C} \mathrm{m}^{-2} \mathrm{~h}^{-1}$, which occurred near $50 \%$ heading in all cultivars (i.e., 56 DAF for Cheniere and CLXL745 and 63 DAF for Taggart) and did not differ, followed by a decrease in fluxes up to the time of flood release. Methane fluxes from Cheniere and Taggart only differed at 42 DAF, where fluxes were greater from Cheniere, while the hybrid cultivar, CLXL745, had significantly lower fluxes than Cheniere on four of six sampling dates prior to heading and lower fluxes than Cheniere and Taggart on two of three dates following heading.

Reduced $\mathrm{CH}_{4}$ fluxes from CLXL745 relative to Cheniere and Taggart were similarly observed by Rogers et al. [26], especially toward the end of the season where fluxes from CLXL745 decreased much more rapidly than those from the pure-line cultivars. Additional studies have also observed reduced fluxes from hybrid relative to pure-line cultivars $[25,27,28]$. Ma et al. [25] measured lower dissolved $\mathrm{CH}_{4}$ concentrations and increased methanotrophic bacteria in the rhizosphere of hybrid rice accompanied by a $67 \%$ increase in 


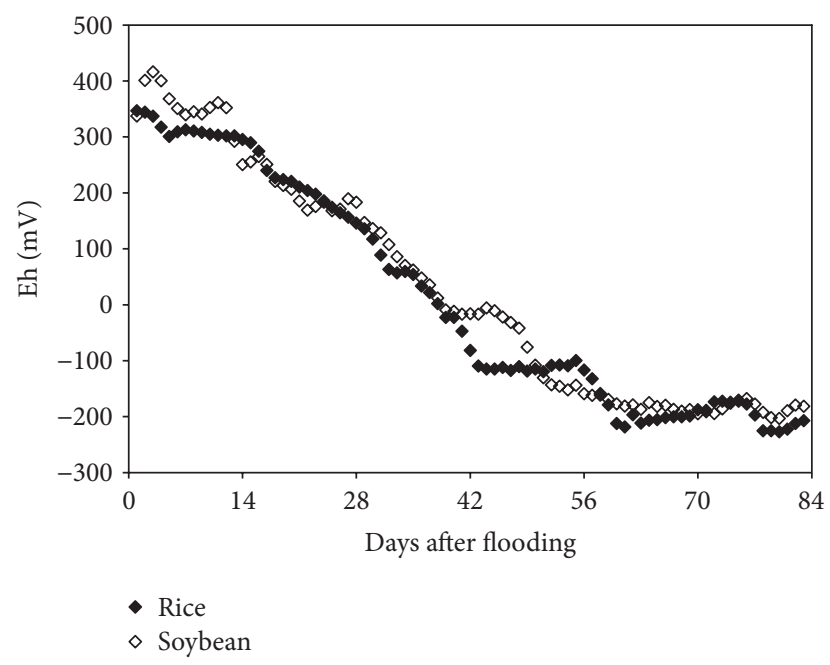

FIGURE 3: Soil oxidation-reduction potential (Eh) at the $7.5 \mathrm{~cm}$ depth over the flooded portion of the 2013 growing season for CLXL745 and Cheniere at the Northeast Research and Extension Center in Keiser, Arkansas.

$\mathrm{CH}_{4}$ oxidation potential relative to pure-line cultivars, while all cultivars had similar $\mathrm{CH}_{4}$ production potentials. This indicates that reduced $\mathrm{CH}_{4}$ fluxes from hybrid cultivars may be due to differences in microbial community structure, where greater methanotrophic activity reduces $\mathrm{CH}_{4}$ transport to the atmosphere by oxidizing a greater proportion of the produced $\mathrm{CH}_{4}$. Similar to this study, Rogers et al. [26] observed only minor differences in $\mathrm{CH}_{4}$ fluxes between Cheniere and Taggart, while previous studies have reported reduced fluxes from semidwarf relative to standard-stature cultivars [22-24].

While the relative treatment differences and flux trends measured in this study were consistent with previous studies, the magnitude of peak fluxes was on the low end of peaks measured from similar studies conducted on clay and clayloam soils, which ranged from 2.1 to $25 \mathrm{mg} \mathrm{CH}_{4}-\mathrm{C} \mathrm{m}^{-2} \mathrm{~h}^{-1}$ $[17,29-31,66]$. On a silt-loam soil in Arkansas under similar management and methodology to this study, Rogers et al. [26] observed peak fluxes at heading ranging from $8.3 \mathrm{mg} \mathrm{CH}_{4}{ }^{-}$ $\mathrm{C} \mathrm{m}^{-2} \mathrm{~h}^{-1}$ for CLXL745 following soybean to $18.7 \mathrm{mg} \mathrm{CH}_{4}$ $\mathrm{C} \mathrm{m}^{-2} \mathrm{~h}^{-1}$ for CLXL745 following rice. The low magnitude of fluxes observed in this study is likely large due to the high clay content, as several studies have indicated greater fluxes from coarse soils than those from fine-textured soils $[23,32,43]$. The low fluxes measured in this study may also be partially explained by soil Eh trends.

Soil Eh did not differ substantially between rice or soybean previous crops (data not shown); however, when averaged across previous crop, soil Eh was consistently lower from Cheniere than CLXL745 until approximately 60 DAF, after which soil Eh did not appear to differ much among cultivars and stabilized near $-200 \mathrm{mV}$ (Figure 3). Lower soil Eh prior to heading was indicative of more reduced conditions and greater potential for methanogenesis from Cheniere relative to CLXL745, which is consistent with $\mathrm{CH}_{4}$ flux observations. The reason for the difference in soil Eh is not well understood but may be related to a difference in

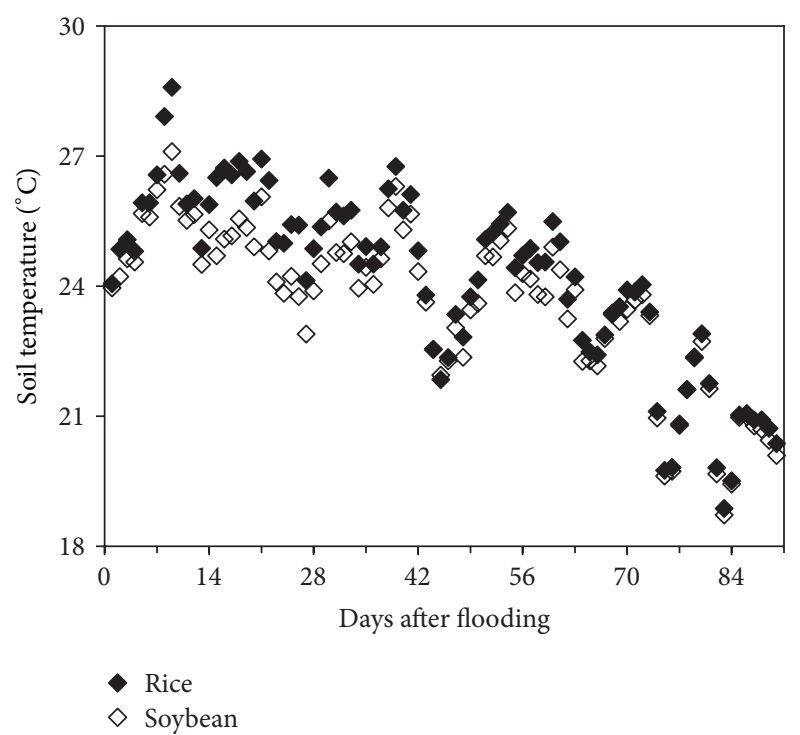

Figure 4: Daily mean soil temperature at the $7.5 \mathrm{~cm}$ depth over the flooded portion of the 2013 growing season for rice and soybean previous crop treatments at the Northeast Research and Extension Center in Keiser, Arkansas.

root development and exudation as a degradable $\mathrm{C}$ supply for redox reactions or a difference in aerenchyma development or root structure that may result in greater oxygenation in the rhizosphere of CLXL745. Similar soil Eh at heading was consistent with observed fluxes; however, the greater reduction in fluxes from CLXL745 following heading was not reflected in soil Eh measurements but may have been a result of greater methanotrophic activity in the rhizosphere of the hybrid as observed by Ma et al. [25]. The general stabilization of soil Eh following heading may be a result of the decrease in root exudation observed in previous studies, which would limit the supply of degradable $\mathrm{C}$ and suppress a further drop in soil Eh as well as causing a reduction in methanogenesis.

In addition to soil Eh, low fluxes measured in this study may have also been partially the result of soil temperature variations. Average daily soil temperatures at the $7.5 \mathrm{~cm}$ depth ranged from 22 to $28.6^{\circ} \mathrm{C}$ for the first 10 weeks of flooding, before dropping as low as $18.7^{\circ} \mathrm{C}$ in the last few weeks of the growing season, and over the flooded portion of the growing season averaged 24.5 and $23.9^{\circ} \mathrm{C}$ following rice and soybean, respectively (Figure 4). While the seasonal trend in soil temperature did not appear to drive $\mathrm{CH}_{4}$ flux trends, the unexpected decrease in fluxes at $49 \mathrm{DAF}$ (Figures 1 and 2) may largely be due to uncharacteristically low temperatures in the week prior to $49 \mathrm{DAF}$. This period of low soil temperatures may have reduced fluxes at $49 \mathrm{DAF}$ and likely caused a reduction in peak fluxes, which otherwise would have likely followed the preheading trend of continually increasing fluxes, as well as a reduction in fluxes following heading. Beyrouty et al. [67] observed an influence of soil temperature on root growth, suggesting that the low temperatures prior to 49 DAF may have slowed root growth and enhanced the effect of low temperatures reducing fluxes as observed in other studies $[68,69]$. Average daily soil temperatures were consistently 
lower following soybean compared to rice, especially early in the season, as a result of faster canopy development in rice where soybean was the previous crop, which provided greater shading to the soil. The difference in canopy between rice following previous crops lessened over the growing season and had little impact by maturation. Greater soil temperatures following rice may partially explain greater fluxes following rice; however, the differences in temperature were small relative to the difference in fluxes, indicating that fluxes are more strongly influenced by the quantity and quality of previous crop inputs or by differences in microbial communities based on previous cropping system.

3.3. Methane Fluxes following Flood Release. After the flood was released, $\mathrm{CH}_{4}$ fluxes differed over time ( $\left.p=0.002\right)$, while previous crop and cultivar had no impact on the magnitude of fluxes (Table 2). Methane fluxes in all treatment combinations were below $0.46 \mathrm{mg} \mathrm{CH}_{4}-\mathrm{C} \mathrm{m}^{-2} \mathrm{~h}^{-1}$ on the last sampling date prior to flood release and did not change substantially by 1 DAFR, averaging $0.29 \mathrm{mg} \mathrm{CH}_{4}-\mathrm{C} \mathrm{m}^{-2} \mathrm{~h}^{-1}$. Averaged across all treatment combinations, post-flood-release $\mathrm{CH}_{4}$ fluxes were the greatest at $3 \mathrm{DAFR}$, averaging $0.65 \mathrm{mg} \mathrm{CH}_{4}$ $\mathrm{C} \mathrm{m}^{-2} \mathrm{~h}^{-1}$, while mean fluxes on the remaining sampling dates did not differ from each other but achieved a minimum value of $0.05 \mathrm{mg} \mathrm{CH}_{4}-\mathrm{C} \mathrm{m}^{-2} \mathrm{~h}^{-1}$ on the last sampling date (7 DAFR). The post-flood-release $\mathrm{CH}_{4}$ pulse observed in this study has been recorded by numerous other studies [26$28,39,42,44]$, generally occurring from 3 to 6 DAFR, and is thought to result from the drying of soil macropores which release entrapped $\mathrm{CH}_{4}[70,71]$. Similar to results obtained prior to flood release, $\mathrm{CH}_{4}$ fluxes measured following flood release were lower than those observed in similar studies on silt-loam soils in Arkansas, which reported post-flood-release peak $\mathrm{CH}_{4}$ fluxes ranging from 4.5 to $15 \mathrm{mg} \mathrm{CH}_{4}-\mathrm{C} \mathrm{m}^{-2} \mathrm{~h}^{-1}$ $[26,42]$. This difference is likely a result of soil textural differences as it has been demonstrated that clayey soils can result in increased $\mathrm{CH}_{4}$ oxidation due to greater tortuosity and slower diffusion of gases through clay soils [23].

3.4. Aboveground Dry Matter and Grain Yield. Sampling location (i.e., in-chamber or in-plot) had no effect ( $p=0.845$ ) on aboveground dry matter measured at the end of the growing season, indicating that the chambers did not adversely affect plant growth. Aboveground dry matter differed, however, between previous crops among cultivars $(p=0.032)$. Averaged across sampling location, aboveground dry matter following rice as the previous crop was greater from CLXL745 than that from Cheniere or Taggart, which did not differ and averaged about 20\% lower than CLXL745 (Table 3). Following soybean as a previous crop, aboveground dry matter was also about 20\% lower from Cheniere than that from CLXL745 and Taggart, which did not differ.

Similar to aboveground dry matter, grain yield differed between previous crops among cultivars $(p=0.044)$. Grain yields from CLXL745 and Taggart were greater when following soybean than those when following rice, while grain yields from Cheniere did not differ based on previous crop (Table 3). When rice was the previous crop, CLXL745 had a
TABLE 3: Mean aboveground dry matter and yields collected at harvest (24 October, 2013) from Cheniere, CLXL745, and Taggart following previous crops of rice and soybean at the Northeast Research and Extension Center in Keiser, Arkansas.

\begin{tabular}{lccc}
\hline Plant property/previous crop & Cheniere & CLXL745 & Taggart \\
\hline Aboveground dry matter $\left(\mathrm{kg} \mathrm{m}^{-2}\right)$ & & & \\
$\quad$ Rice & $1.76^{\mathrm{bA} \dagger}$ & $2.17^{\mathrm{aA}}$ & $1.77^{\mathrm{bA}}$ \\
$\quad$ & $1.83^{\mathrm{bA}}$ & $2.23^{\mathrm{aA}}$ & $2.26^{\mathrm{aA}}$ \\
\hline Soybean & & & \\
Grain yield $\left(\mathrm{Mg} \mathrm{ha}^{-1}\right)$ & $9.3^{\mathrm{bA} \dagger}$ & $9.9^{\mathrm{aB}}$ & $9.7^{\mathrm{abB}}$ \\
Rice & $9.5^{\mathrm{cA}}$ & $11.0^{\mathrm{aA}}$ & $10.4^{\mathrm{bA}}$ \\
$\quad$ Soybean & &
\end{tabular}

${ }^{\dagger}$ Different lowercase letters in the same previous crop for a plant property indicate differences among cultivars and different uppercase letters within a column for a plant property indicate differences between previous crops $(p<0.05)$.

greater grain yield than Cheniere, while Taggart did not differ from either. Similarly, following soybean, grain yields differed in all cultivars, with CLXL745 attaining the greatest yield and Cheniere the lowest. Grain yields achieved in this study, which ranged from $9.3 \mathrm{Mg} \mathrm{ha}^{-1}$ for Cheniere following rice to $11.0 \mathrm{Mg} \mathrm{ha}^{-1}$ for CLXL745 following soybean, were similar to 3 -year means reported for Arkansas Rice Performance trials (i.e., $8.9 \mathrm{Mg} \mathrm{ha}^{-1}$ for Cheniere (2010 to 2012), $9.5 \mathrm{Mg} \mathrm{ha}^{-1}$ for CLXL745 (2011 to 2013), and $10.3 \mathrm{Mg} \mathrm{ha}^{-1}$ for Taggart (2011 to 2013)) $[49,72]$.

3.5. Seasonal Methane Emissions. As expected, based on $\mathrm{CH}_{4}$ flux measurements, season-long area-scaled $\mathrm{CH}_{4}$ emissions differed by both previous crop $(p=0.003)$ and cultivar $(p=0.034)$ (Table 4). Averaged across cultivar, area-scaled $\mathrm{CH}_{4}$ emissions were greater following rice as a previous crop $\left(19.6 \mathrm{~kg} \mathrm{CH}_{4}-\mathrm{C} \mathrm{ha}^{-1}\right.$ season $\left.^{-1}\right)$ than those following soybean $\left(7.0 \mathrm{~kg} \mathrm{CH}_{4}-\mathrm{Cha}^{-1}\right.$ season $^{-1}$ ) (Table 5). Many studies have reported an increase in $\mathrm{CH}_{4}$ emissions with increasing additions of rice straw, indicating the importance of residue inputs on emissions [9, 66, 73-75]. Rogers et al. [26] reported a similar trend, although emissions were only reduced by $31 \%$ following soybean compared to those following rice, whereas a reduction of $64 \%$ was measured in this study. The observations made in this study are consistent with results indicating reduced fluxes resulting from a reduction in residue inputs prior to flooding. Reduced fluxes when following soybean as a previous crop are likely a result of lower residue inputs as well as increased decomposition of the more labile soybean residue under aerobic conditions.

Averaged across previous crop, season-long area-scaled $\mathrm{CH}_{4}$ emissions from CLXL745 (10.2 $\mathrm{kg} \mathrm{CH}_{4}-\mathrm{C} \mathrm{ha}^{-1}$ season $^{-1}$ ) were reduced by $31 \%$ relative to Cheniere and Taggart, which did not differ and averaged $14.9 \mathrm{~kg} \mathrm{CH}_{4}-\mathrm{Cha}^{-1}$ season $^{-1}$ (Table 5). The reduction in emissions from CLXL745 is consistent with previous studies that have reported a $37 \%$ reduction from CLXL745 relative to Cheniere and Taggart [26], a 25\% reduction from CLXL745 relative to Francis and Jupiter [27], and a $30 \%$ average reduction from three hybrid cultivars (CLXL729, CLXL745, and XL753), which did not differ, relative to the standard-stature, pure-line cultivar Roy J [28]. 
TABLE 4: Summary of the effect of previous crop, cultivar, and their interaction on seasonal methane $\left(\mathrm{CH}_{4}\right)$ emissions from a clay soil during the 2013 growing season at the Northeast Research and Extension Center in Keiser, Arkansas.

\begin{tabular}{lccc}
\hline Emissions property & Previous crop & Cultivar & Previous crop $\times$ cultivar \\
& & 0.034 & 0.122 \\
Area-scaled emissions $\left(\mathrm{kg} \mathrm{CH}_{4}-\mathrm{C} \mathrm{ha}^{-1}\right.$ season $\left.^{-1}\right)$ & 0.003 & 0.017 & 0.111 \\
Yield-scaled emissions $\left(\mathrm{kg} \mathrm{CH}_{4}-\mathrm{C}\left(\mathrm{Mg}\right.\right.$ grain $\left.^{-1}\right)$ & 0.004 & 0.968 & 0.781 \\
Postflood emissions $\left(\mathrm{kg} \mathrm{CH}_{4}-\mathrm{C} \mathrm{ha}^{-1}\right)$ & 0.139 & 0.877 & 0.841 \\
Postflood emissions (\% total emissions) & 0.367 & & \\
\hline
\end{tabular}

TABLE 5: Season-long methane $\left(\mathrm{CH}_{4}\right)$ emissions as affected by previous crop and rice cultivar expressed on an area- and yield-scaled basis from the 2013 growing season on a clay soil at the Northeast Research and Extension Center in Keiser, Arkansas.

\begin{tabular}{|c|c|c|c|c|}
\hline Property/effect & Cheniere & CLXL745 & Taggart & Mean \\
\hline \multicolumn{5}{|c|}{ Area-scaled emissions $\left(\mathrm{kg} \mathrm{CH}_{4}-\mathrm{Cha}^{-1}\right.$ season $\left.^{-1}\right)$} \\
\hline Rice & 23.9 & 14.6 & 20.4 & $19.6^{\mathrm{A}}$ \\
\hline Soybean & 7.0 & 5.8 & 8.1 & $7.0^{\mathrm{B}}$ \\
\hline Mean & $15.5^{\mathrm{a} \dagger}$ & $10.2^{\mathrm{b}}$ & $14.2^{\mathrm{a}}$ & \\
\hline \multicolumn{5}{|c|}{ Yield-scaled emissions $\left(\mathrm{kg} \mathrm{CH}_{4}-\mathrm{C}(\mathrm{Mg} \text { grain })^{-1}\right)$} \\
\hline Rice & 2.59 & 1.45 & 2.11 & $2.05^{\mathrm{A}}$ \\
\hline Soybean & 0.74 & 0.53 & 0.78 & $0.68^{\mathrm{B}}$ \\
\hline Mean & $1.66^{\mathrm{a} \dagger}$ & $0.99^{\mathrm{b}}$ & $1.45^{\mathrm{a}}$ & \\
\hline
\end{tabular}

${ }^{\dagger}$ Different lowercase letters within a row for a measured property indicate differences among cultivars and different uppercase letters within a column for a measured property indicate differences between previous crop treatments $(p<0.05)$.

While little research has focused on determining how emissions are reduced from hybrid cultivars, Ma et al. [25] observed an increase in methanotrophic bacteria and $\mathrm{CH}_{4}$ oxidation from hybrid rice relative to pure-line cultivars, which is consistent with greater redox potentials observed in the rhizosphere of CLXL745 in this study (Figure 3). Butterbach-Bahl et al. [15] attributed a 24 to $31 \%$ reduction in emissions from one cultivar relative to another (both pure-lines) to differences in transport capacity between the cultivars. Aulakh et al. [21] observed a positive correlation between total organic $\mathrm{C}$ from root exudates and $\mathrm{CH}_{4}$ production potential, indicating the potential for cultivar differences in emissions based on variable root exudation rates. While the impacts of variable $\mathrm{CH}_{4}$ oxidation rates, transport capacities, and root exudation rates are not well understood, evidence has consistently demonstrated a reduction in $\mathrm{CH}_{4}$ emissions from hybrid cultivars grown in the US, particularly from CLXL745 grown in Arkansas [26-28].

Similar to this study, Rogers et al. [26] observed no difference in area-scaled emissions between Cheniere and Taggart, while several previous studies have reported reduced emissions from semidwarf relative to standard-stature cultivars [22-24]. The difference in fluxes between semidwarf and standard-stature cultivars in previous studies may be due to a positive correlation between plant biomass and $\mathrm{C}$ exudation rates from roots [21] or between aboveground dry matter and $\mathrm{CH}_{4}$ emissions [17, 19, 20,76]. While a reduction in emissions from semidwarf cultivars is oftentimes linked to reduced dry matter accumulation, this study, as well as Rogers et al's [26], observed a reduction in aboveground dry matter that was not accompanied by a reduction in emissions. Cultivars are being developed in the United States for reduced plant height and shorter growth duration, as breeding programs are focusing on the development of semidwarf and hybrid cultivars, but the aboveground morphological characteristics associated with new cultivars (i.e., shorter plants and presumably lower leaf area) may not relate to $\mathrm{CH}_{4}$ emissions. Furthermore, using data from the Arkansas Rice Performance trials [72] for the cultivars used in this study, neither area- or yield-scaled emissions were correlated $(p>0.05)$ to plant height.

As was the case with area-scaled emissions, yield-scaled emissions varied based on both previous crop $(p=0.004)$ and cultivar ( $p=0.017$, Table 4$)$. Yield-scaled emissions, averaged across cultivar, were reduced by $67 \%$ following soybean $\left(0.7 \mathrm{~kg} \mathrm{CH}_{4}-\mathrm{C}(\mathrm{Mg} \text { grain })^{-1}\right)$ compared to those following rice as a previous crop $\left(2.1 \mathrm{~kg} \mathrm{CH}_{4}-\mathrm{C}(\mathrm{Mg} \text { grain })^{-1}\right)$ and, averaged across previous crop, emissions from CLXL745 $\left(1.0 \mathrm{~kg} \mathrm{CH}_{4}-\mathrm{C}(\mathrm{Mg} \text { grain })^{-1}\right)$ were reduced by $36 \%$ relative to Cheniere and Taggart, which did not differ and averaged $1.6 \mathrm{~kg} \mathrm{CH}_{4}-\mathrm{C}(\mathrm{Mg} \text { grain) })^{-1}$ (Table 5). While the difference in yield-scaled emissions following soybean compared to rice as a previous crop is greater than previously reported from a silt-loam soil (i.e., 31\% reduction following soybean), the reduction in emissions from CLXL745 is consistent with an average reduction of $44 \%$ relative to Cheniere and Taggart reported by Rogers et al. [26]. Yield-scaled emissions measured in this study, however, were only about $10 \%$ of those reported by Rogers et al. [26], which ranged from 11.1 to $20.5 \mathrm{~kg} \mathrm{CH}_{4}-\mathrm{C}(\mathrm{Mg} \text { grain })^{-1}$, indicating a strong suppression of $\mathrm{CH}_{4}$ emissions from a clay relative to a silt-loam soil under similar management and production practices. 
Methane emissions following flood release were unaffected $(p>0.05)$ by previous crop or cultivar both on an areascaled basis and as a percentage of total emissions (Table 4). Averaged across all treatment combinations, postflood emissions amounted to $0.6 \mathrm{~kg} \mathrm{CH}_{4}-\mathrm{C} \mathrm{ha}^{-1}$, which was equivalent to an average of $4.5 \%$ of total season-long, area-scaled emissions. The proportion of $\mathrm{CH}_{4}$ emitted following flood release in this study was much less than post-flood-release emissions of 10.5, 13, and 16\% from CLXL745, Taggart, and Cheniere, respectively, reported by Rogers et al. [26] from a silt-loam soil, which may be a result of greater $\mathrm{CH}_{4}$ oxidation in the clay soil reducing the amount of built-up $\mathrm{CH}_{4}$ that is released upon soil drying. Post-flood-release $\mathrm{CH}_{4}$ emissions observed in this study, however, were similar to the $5.1 \%$ reported by Smartt [40] and the 5.2\% reported by Rogers et al. [42]. Additional studies have reported post-floodrelease emissions ranging from 7 to $20 \%$ of total area-scaled emissions $[34,70,77]$. While the magnitude and fraction of post-flood-release emissions vary, it is apparent that, under certain conditions, $\mathrm{CH}_{4}$ builds up in the soil and is rapidly released in a pulse as the soil dries and macropores become accessible for gas movement.

Season-long, area-scaled emissions measured in this study (Table 5) only amounted to 4 to $11 \%$ of the current USEPA emission factor for non-California, primary rice crops (178 $\mathrm{kg} \mathrm{CH}_{4}-\mathrm{Cha}^{-1}$ ) and were substantially less than the lowest reported emissions used in calculating that factor (i.e., emissions ranged from 46 to $375 \mathrm{~kg} \mathrm{CH}_{4}-\mathrm{C} \mathrm{ha}^{-1}$ ), many of which were measured on clay soils in Texas [37]. Similarly, emissions measured in this study were only about $10 \%$ of those measured from a similar study on a silt-loam soil in eastern Arkansas [26]. Studies in California, however, have reported emissions of similar magnitudes (i.e., 6.7 to $14 \mathrm{~kg} \mathrm{CH}_{4}-\mathrm{Cha}^{-1}$ ) from a Capay silty clay (48\% clay) and from a Clear Lake clay (59\% clay, 9.2 to $19 \mathrm{~kg} \mathrm{CH}_{4}-\mathrm{C} \mathrm{ha}^{-1}$ ), while also reporting emissions ranging from 58 to $69 \mathrm{~kg} \mathrm{CH}_{4}^{-}$ $\mathrm{C} \mathrm{ha}^{-1}$ from another site with $47 \%$ clay $[27,44]$.

While emissions have been shown to be quite variable, even within studies on clay soils, it is likely that a textural effect is largely the cause for low emissions observed in this study. This is likely due to the impact of increasing clay content causing an increase in tortuosity and a decrease in diffusivity, effectively limiting $\mathrm{CH}_{4}$ movement out of finetextured soils [61, 78]. Multiple studies have observed an increase in $\mathrm{CH}_{4}$ entrapment and decrease in emissions resulting from increasing clay contents $[64,70]$ and Sass and Fisher [23] attributed the reduction in $\mathrm{CH}_{4}$ emissions from clay soils to the entrapment and slow movement of $\mathrm{CH}_{4}$ that allows more $\mathrm{CH}_{4}$ to be oxidized in aerated zones surrounding roots and at the soil surface. Wang et al. [64] observed varying degrees of $\mathrm{CH}_{4}$ entrapment, even among soils with similar sand and clay contents, where the greatest entrapment (98.5\%) was measured from a Sharkey clay soil compared to 80.6 and $67.8 \%$ entrapment from Beaumont clay and Sacramento clay, respectively. These results suggest that more than simple particle-size distribution affects $\mathrm{CH}_{4}$ emissions and that the low emissions measured in this study likely reflect a large magnitude of $\mathrm{CH}_{4}$ entrapment and oxidation in the Sharkey clay soil investigated.

Additional evidence suggesting large $\mathrm{CH}_{4}$ oxidation rates in this study is provided by an examination of the soil Eh and temperature recorded in this study. Soil Eh decreased more slowly, while attaining a similar final Eh, in this study compared to a similar study conducted at the same site in 2012, which reported emissions of $35.6 \mathrm{~kg} \mathrm{CH}_{4}-\mathrm{C} \mathrm{ha}^{-1}$ [40]. Similarly, Rogers et al. [42] and Bossio et al. [30] reported faster decreases and lower Eh values, even reaching as low as $-275 \mathrm{mV}$, accompanied by greater emissions than those observed in this study. While lower soil Eh is likely to result in increased $\mathrm{CH}_{4}$ production, Kludze et al. [79] also confirmed that a smaller proportion of $\mathrm{CH}_{4}$ is oxidized by methanotrophs as soil Eh decreases, which supports greater oxidation rates in this study.

\section{Conclusions}

Emissions measured in this study only amounted to 4 to $11 \%$ of the current USEPA emission factor $\left(178 \mathrm{~kg} \mathrm{CH}_{4}-\mathrm{Cha}^{-1}\right)$ and were lower than most previous studies. The large reduction in emissions here, relative to other studies, was likely a result of a large degree of $\mathrm{CH}_{4}$ entrapment in the Sharkey clay resulting in a large degree of $\mathrm{CH}_{4}$ oxidation by methanotrophs. Low emissions were also likely partially attributable to lower soil temperatures as emissions were reduced substantially from those reported for the same site and management of the previous season. Based on low emissions from clay soils, in combination with reductions when following soybean as a previous crop and from hybrid cultivars, it appears that emissions from rice in the mi-southern US may be less than current estimates.

\section{Competing Interests}

The authors declare that there are no competing interests regarding the publication of the paper.

\section{Acknowledgments}

The authors would like to acknowledge the Arkansas Rice Research and Promotion Board for supporting this research. Additional appreciation goes to Mike Duren, Donna Frizzell, Chuck Pipkins, Taylor Adams, Douglas Wolf, Anthony Fulford, and Chester Greub for their assistance in the field and laboratory.

\section{References}

[1] United States Environmental Protection Agency, Global Anthropogenic Non- $\mathrm{CO}_{2}$ Greenhouse Gas Emissions: 1990-2020, 2006, http://nepis.epa.gov/Adobe/PDF/2000ZL5G.PDF.

[2] P. Smith, D. Martino, Z. Cai et al., "Agriculture," in Climate Change 2007: The Physical Science Basis, S. Solomon, D. Qin, M. Manning et al., Eds., Contribution of Working Group I to the Fourth Assessment Report of the Intergovernmental Panel on Climate Change, Cambridge University Press, Cambridge, UK, 2007. 
[3] P. Forster, V. Ramaswamy, P. Artaxo et al., "Changes in atmospheric constituents and in radiative forcing," in Climate Change 2007: The Physical Science Basis, S. Solomon, D. Qin, M. Manning et al., Eds., Contribution of Working Group I to the Fourth Assessment Report of the Intergovernmental Panel on Climate Change, Cambridge University Press, Cambridge, UK, 2007.

[4] B. Linquist, K. J. van Groenigen, M. A. Adviento-Borbe, C. Pittelkow, and C. Van Kessel, "An agronomic assessment of greenhouse gas emissions from major cereal crops," Global Change Biology, vol. 18, no. 1, pp. 194-209, 2011.

[5] B. A. Linquist, M. A. Adviento-Borbe, C. M. Pittelkow, C. van Kessel, and K. J. van Groenigen, "Fertilizer management practices and greenhouse gas emissions from rice systems: a quantitative review and analysis," Field Crops Research, vol. 135, pp. 10-21, 2012.

[6] L. Nazaries, J. C. Murrell, P. Millard, L. Baggs, and B. K. Singh, "Methane, microbes and models: fundamental understanding of the soil methane cycle for future predictions," Environmental Microbiology, vol. 15, no. 9, pp. 2395-2417, 2013.

[7] W. Armstrong, "Radial oxygen losses from intact rice roots as affected by distance from the apex, respiration and waterlogging," Physiologia Plantarum, vol. 25, no. 2, pp. 192-197, 1971.

[8] R. Conrad and F. Rothfuss, "Methane oxidation in the soil surface layer of a flooded rice field and the effect of ammonium," Biology and Fertility of Soils, vol. 12, no. 1, pp. 28-32, 1991.

[9] H. Schütz, W. Seiler, and R. Conrad, "Processes involved in formation and emission of methane in rice paddies," Biogeochemistry, vol. 7, no. 1, pp. 33-53, 1989.

[10] F. Rothfuss and R. Conrad, "Effect of gas bubbles on the diffusive flux of methane in anoxic paddy soil," Limnology and Oceanography, vol. 43, no. 7, pp. 1511-1518, 1998.

[11] A. Holzapfel-Pschorn, R. Conrad, and W. Seiler, "Production, oxidation and emission of methane in rice paddies," FEMS Microbiology Ecology, vol. 1, no. 6, pp. 343-351, 1985.

[12] A. Holzapfel-Pschorn, R. Conrad, and W. Seiler, "Effects of vegetation on the emission of methane from submerged paddy soil," Plant and Soil, vol. 92, no. 2, pp. 223-233, 1986.

[13] R. L. Sass, F. M. Fisher, P. A. Harcombe, and F. T. Turner, "Methane production and emission in a Texas rice field," Global Biogeochemical Cycles, vol. 4, no. 1, pp. 47-68, 1990.

[14] R. L. Sass, F. M. Fisher, Y. B. Wang, F. T. Turner, and M. F. Jund, "Methane emission from rice fields: the effect of floodwater management," Global Biogeochemical Cycles, vol. 6, no. 3, pp. 249-262, 1992.

[15] K. Butterbach-Bahl, H. Papen, and H. Rennenberg, "Impact of gas transport through rice cultivars on methane emission from rice paddy fields," Plant, Cell and Environment, vol. 20, no. 9, pp. 1175-1183, 1997.

[16] I. Nouchi, S. Mariko, and K. Aoki, "Mechanism of methane transport from the rhizosphere to the atmosphere through rice plants," Plant Physiology, vol. 94, no. 1, pp. 59-66, 1990.

[17] R. L. Sass, F. M. Fisher, F. T. Turner, and M. F. Jund, "Methane emission from rice fields as influenced by solar radiation, temperature, and straw incorporation," Global Biogeochemical Cycles, vol. 5, no. 4, pp. 335-350, 1991.

[18] G. J. Whiting and J. P. Chanton, "Primary production control of methane emission from wetlands," Nature, vol. 364, no. 6440, pp. 794-795, 1993.

[19] Y. Huang, R. L. Sass, and F. M. Fisher, "Methane emission from Texas rice paddy soils. 2. Seasonal contribution of rice biomass production to $\mathrm{CH}_{4}$ emission," Global Change Biology, vol. 3, no. 6, pp. 491-500, 1997.
[20] Q. Shang, X. Yang, C. Gao et al., "Net annual global warming potential and greenhouse gas intensity in Chinese double ricecropping systems: a 3-year field measurement in long-term fertilizer experiments," Global Change Biology, vol. 17, no. 6, pp. 2196-2210, 2011.

[21] M. S. Aulakh, R. Wassmann, C. Bueno, J. Kreuzwieser, and H. Rennenberg, "Characterization of root exudates at different growth stages of ten rice (Oryza sativa L.) cultivars," Plant Biology, vol. 3, no. 2, pp. 139-148, 2001.

[22] C. W. Lindau, P. K. Bollich, and R. D. DeLaune, "Effect of rice variety on methane emission from Louisiana rice," Agriculture, Ecosystems \& Environment, vol. 54, no. 1-2, pp. 109-114, 1995.

[23] R. L. Sass and F. M. Fisher Jr., "Methane emissions from rice paddies: a process study summary," Nutrient Cycling in Agroecosystems, vol. 49, no. 1-3, pp. 119-127, 1997.

[24] L. K. Sigren, G. T. Byrd, F. M. Fisher, and R. L. Sass, "Comparison of soil acetate concentratons and methane producton, transport, and emission in two rice cultivars," Global Biogeochemical Cycles, vol. 11, no. 1, pp. 1-14, 1997.

[25] K. Ma, Q. Qiu, and Y. Lu, "Microbial mechanism for rice variety control on methane emission from rice field soil," Global Change Biology, vol. 16, no. 11, pp. 3085-3095, 2010.

[26] C. W. Rogers, K. R. Brye, A. D. Smartt, R. J. Norman, E. E. Gbur, and M. A. Evans-White, "Cultivar and previous crop effects on methane emissions from drill-seeded, delayed-flood rice production on a silt-loam soil," Soil Science, vol. 179, pp. 2836, 2014.

[27] M. B. Simmonds, M. Anders, M. A. Adviento-Borbe, C. van Kessel, A. McClung, and B. A. Linquist, "Seasonal methane and nitrous oxide emissions of several rice cultivars in direct-seeded systems," Journal of Environmental Quality, vol. 44, no. 1, pp. 103-114, 2015.

[28] A. D. Smartt, C. W. Rogers, K. R. Brye et al., "Growing-season methane fluxes and emissions from a silt-loam soil as influenced by rice cultivar," in B.R. Wells Rice Research Studies, 2014, R. J. Norman and K. A. K. Moldenhauer, Eds., vol. 626 of Arkansas Agricultural Experiment Station Research Series, pp. 289-297, Fayetteville, Ark, USA, 2015.

[29] R. J. Cicerone, C. C. Delwiche, S. C. Tyler, and P. R. Zimmerman, "Methane emissions from California rice paddies with varied treatments," Global Biogeochemical Cycles, vol. 6, no. 3, pp. 233248, 1992.

[30] D. A. Bossio, W. R. Horwath, R. G. Mutters, and C. van Kessel, "Methane pool and flux dynamics in a rice field following straw incorporation," Soil Biology \& Biochemistry, vol. 31, no. 9, pp. 1313-1322, 1999.

[31] G. J. Fitzgerald, K. M. Scow, and J. E. Hill, "Fallow season straw and water management effects on methane emissions in California rice," Global Biogeochemical Cycles, vol. 14, no. 3, pp. 767-776, 2000.

[32] R. L. Sass, F. M. Fisher, S. T. Lewis, F. T. Turner, and M. F. Jund, "Methane emissions from rice fields: effect of soil properties," Global Biogeochemical Cycles, vol. 8, no. 2, pp. 135-140, 1994.

[33] H. A. C. Denier van der Gon and H. U. Neue, "Influence of organic matter incorporation on the methane emission from a wetland rice field," Global Biogeochemical Cycles, vol. 9, no. 1, pp. 11-22, 1995.

[34] K. Yagi, H. Tsuruta, and K. Minami, "Possible options for mitigating methane emission from rice cultivation," Nutrient Cycling in Agroecosystems, vol. 49, no. 1-3, pp. 213-220, 1997.

[35] R. L. Sass, F. M. Fisher Jr., A. Ding, and Y. Huang, "Exchange of methane from rice fields: national, regional, and global 
budgets," Journal of Geophysical Research Atmospheres, vol. 104, no. 21, pp. 26943-26951, 1999.

[36] Intergovernmental Panel on Climate Change, "Cropland," in 2006 IPCC Guidelines for National Greenhouse Gas Inventories, vol. 4 of Agriculture, Forestry and Other Land Use, chapter 5, pp. 5.1-5.66, 2006, http://www.ipcc-nggip.iges.or.jp/public/2006gl/ pdf/4_Volume4/V4_05_Ch5_Cropland.pdf.

[37] United States Environmental Protection Agency, Inventory of U.S. Greenhouse Gas Emissions and Sinks: 1990-2013, 2015, http://www.epa.gov/climatechange/Downloads/ghgemissions/ US-GHG-Inventory-2015-Main-Text.pdf.

[38] J. T. Hardke, "Trends in Arkansas rice production," in B.R. Wells Rice Research Studies, 2013, R. J. Norman and K. A. K. Moldenhauer, Eds., vol. 617 of Arkansas Agricultural Experiment Station Research Series, pp. 13-23, Fayetteville, Ark, USA, 2014.

[39] A. D. Smartt, K. R. Brye, R. J. Norman, C. W. Rogers, and M. Duren, "Growing-season methane fluxes from direct-seeded, delayed-flood rice produced on a clay soil," in B.R. Wells Rice Research Studies, 2012, R. J. Norman and K. A. K. Moldenhauer, Eds., vol. 609 of Arkansas Agricultural Experiment Station Research Series, pp. 306-315, 2013.

[40] A. D. Smartt, Influence of vegetation and chamber size on methane emissions from rice production on a clay soil in Arkansas [M.S. thesis], University of Arkansas, Fayetteville, Ark, USA, 2015.

[41] C. W. Rogers, K. R. Brye, R. J. Norman, T. Gasnier, D. Frizzell, and J. Branson, "Methane emissions from a silt-loam soil under direct-seeded, delayed-flood rice management," in $B$. R. Wells Rice Research Studies, 2011, R. J. Norman and K. A. K. Moldenhauer, Eds., vol. 600 of Arkansas Agricultural Experiment Station Research Series, pp. 240-247, 2012.

[42] C. W. Rogers, K. R. Brye, R. J. Norman et al., "Methane emissions from drill-seeded, delayed-flood rice production on a siltloam soil in Arkansas," Journal of Environmental Quality, vol. 42, no. 4, pp. 1059-1069, 2013.

[43] K. R. Brye, C. W. Rogers, A. D. Smartt, and R. J. Norman, "Soil texture effects on methane emissions from direct-seeded, delayed-flood rice production in Arkansas," Soil Science, vol. 178, no. 10, pp. 519-529, 2013.

[44] M. A. Adviento-Borbe, C. M. Pittelkow, M. Anders et al., "Optimal fertilizer nitrogen rates and yield-scaled global warming potential in drill seeded rice," Journal of Environmental Quality, vol. 42, no. 6, pp. 1623-1634, 2013.

[45] Soil Survey Staff, Natural Resources Conservation Service, and United States Department of Agriculture, Web Soil Survey, 2012, http://websoilsurvey.sc.egov.usda.gov/App/HomePage.htm.

[46] Natural Resources Conservation Service and United States Department of Agriculture, Land Resource Regions and Major Land Resource Areas of the United States, the Caribbean, and the Pacific Basin, United States Department of Agriculture Handbook 296, 2006, http://www.nrcs.usda.gov/Internet/FSE_ DOCUMENTS/nrcs142p2_050898.pdf.

[47] National Oceanic and Atmospheric Administration, "Climatography of the United States No. 81: Monthly station normals of temperature, precipitation, and heating and cooling degree days 1971-2000," 2002, http://www.ncdc.noaa.gov/climatenormals/clim81/ARnorm.pdf.

[48] S. D. Linscombe, X. Sha, K. Bearb et al., "Registration of 'Cheniere’ rice," Crop Science, vol. 46, no. 4, pp. 1814-1815, 2006.

[49] J. T. Hardke, D. L. Frizzell, C. E. Wilson Jr. et al., "Arkansas rice performance trials," in B.R. Wells Rice Research Studies, 2012, R.
J. Norman and K. A. K. Moldenhauer, Eds., vol. 609 of Arkansas Agricultural Eexperiment Station Research Series, pp. 222-231, Fayetteville, Ark, USA, 2013.

[50] K. A. K. Moldenhauer, J. W. Gibbons, F. N. Lee et al., "Taggart, high yielding large kernel long-grain rice variety," in $B . R$. Wells Rice Research Studies, 2008, R. J. Norman and K. A. K. Moldenhauer, Eds., vol. 571, pp. 68-73, Arkansas Agricultural Experiment Station Research Series, Fayetteville, Ark, USA, 2008.

[51] J. T. Hardke, “RICESEED,” 2014, http://riceseed.uaex.edu/OptImenu.asp.

[52] J. T. Hardke, Ed., Arkansas Rice Production Handbook, University of Arkansas, Division of Agriculture, Cooperative Extension Service MP192, Little Rock, AK, USA, 2013.

[53] R. Norman, N. Slaton, and T. Roberts, "Soil fertility," in Arkansas Rice Production Handbook, J. T. Hardke, Ed., pp. 69-102, University of Arkansas, Division of Agriculture, Cooperative Extension Service MP192, Little Rock, AK, USA, 2013.

[54] G. Lorenz and J. T. Hardke, "Insect management in rice," in Arkansas Rice Production Handbook, J. T. Hardke, Ed., pp. 139-162, University of Arkansas, Division of Agriculture, Cooperative Extension Service MP192, Little Rock, Ark, USA, 2013.

[55] B. Scott, J. Norsworthy, T. Barber, and J. Hardke, "Rice weed control," in Arkansas Rice Production Handbook, J. T. Hardke, Ed., pp. 53-62, University of Arkansas, Division of Agriculture, Cooperative Extension Service MP 192, Little Rock, AK, USA, 2013.

[56] M. R. Tucker, "Determination of phosphorus by Mehlich 3 extraction," in Soil and Media Diagnostic Procedures for the Southern Region of the United States, S. J. Donohue, Ed., vol. 374, pp. 6-8, Virginia Agricultural Experiment Station Bullitin, Blacksburg, Va, USA, 1992.

[57] D. W. Nelson and L. E. Sommers, "Total carbon, organic carbon, and organic matter," in Methods of Soil Analysis. Part 3: Chemical Analysis, D. L. Sparks, A. L. Page, P. A. Helmke et al., Eds., pp. 961-1010, Soil Science Society of America, Madison, Wis, USA, 3rd edition, 1996.

[58] E. E. Schulte and B. G. Hopkins, "Estimation of organic matter by weight loss-on-ignition," in Soil Organic Matter: Analysis and Interpretation, F. R. Magdoff, M. A. Tabatabai, and E. A. Hanlon Jr., Eds., pp. 21-31, Soil Science Society of America Special, Madison, Wis, USA, 1996.

[59] G. W. Gee and D. Or, "Particle-size analysis," in Methods of Soil Analysis. Part 4: Physical Methods, J. H. Dane and G. C. Topp, Eds., pp. 255-293, Soil Science Society of America, Madison, Wis, USA, 1st edition, 2002.

[60] W. H. Patrick, R. P. Gambrell, and S. P. Faulkner, "Redox measurements of soil," in Methods of Soil Analysis. Part 3: Chemical Analysis, D. L. Sparks, A. L. Page, P. A. Helmke et al., Eds., pp. 1255-1273, Soil Science Society of America, Madison, Wis, USA, 3rd edition, 1996.

[61] G. Livingston and G. Hutchinson, "Enclosure-based measurement of trace gas exchange: applications and sources of error," in Biogenic Trace Gases: Measuring Emissions from Soil and Water, P. A. Matson and R. C. Harriss, Eds., pp. 14-51, Blackwell Sciences, Oxford, UK, 1995.

[62] T. Parkin and R. Venterea, "Chamber-based trace gas flux measurements," in GRACEnet Sampling Protocols, R. Follett, Ed., 2010, http://www.ars.usda.gov/SP2UserFiles/Program/212/ Chapter\%203.\%20GRACEnet\%20Trace\%20Gas\%20Sampling\% 20Protocols.pdf. 
[63] T. B. Parkin, R. T. Venterea, and S. K. Hargreaves, "Calculating the detection limits of chamber-based soil greenhouse gas flux measurements," Journal of Environmental Quality, vol. 41, no. 3, pp. 705-715, 2012.

[64] Z. P. Wang, C. W. Lindau, R. D. Delaune, and W. H. Patrick Jr., "Methane emission and entrapment in flooded rice soils as affected by soil properties," Biology and Fertility of Soils, vol. 16, no. 3, pp. 163-168, 1993.

[65] A. Watanabe and M. Kimura, "Influence of chemical properties of soils on methane emission from rice paddies," Communications in Soil Science and Plant Analysis, vol. 30, no. 17-18, pp. 2449-2463, 1999.

[66] R. L. Sass, F. M. Fisher, F. T. Turner, and M. F. Jund, "Methane emission from rice fields as influenced by solar radiation, temperature, and straw incorporation," Global Biogeochemical Cycles, vol. 5, no. 4, pp. 335-350, 1991.

[67] C. A. Beyrouty, R. J. Norman, B. R. Wells et al., "A decade of rice root characterization studies," in Arkansas Rice Research Studies 1995, R. J. Norman and B. R. Wells, Eds., vol. 453, pp. 920, Arkansas Agricultural Experiment Station Research Series, Fayettevile, Ark, USA, 1996.

[68] T. Hosono and I. Nouchi, "The dependence of methane transport in rice plants on the root zone temperature," Plant and Soil, vol. 191, no. 2, pp. 233-240, 1997.

[69] B. Wang, H. U. Neue, and H. P. Samonte, "The effect of controlled soil temperature on diel $\mathrm{CH}_{4}$ emission variation," Chemosphere, vol. 35, no. 9, pp. 2083-2092, 1997.

[70] H. A. C. Denier van der Gon, N. van Breemen, H.-U. Neue et al., "Release of entrapped methane from wetland rice fields upon soil drying," Global Biogeochemical Cycles, vol. 10, no. 1, pp. 1-7, 1996.

[71] H. U. Neue, R. Wassmann, H. K. Kludze, B. Wang, and R. S. Lantin, "Factors and processes controlling methane emissions from rice fields," Nutrient Cycling in Agroecosystems, vol. 49, no. 1-3, pp. 111-117, 1997.

[72] J. T. Hardke, D. L. Frizzell, E. Castaneda-Gonzalez et al., "Arkansas rice performance trials," in B.R. Wells Rice Research Studies, 2013, R. J. Norman and K. A. K. Moldenhauer, Eds., vol. 617 of Arkansas Agricultural Experiment Station Research Series, pp. 265-273, Arkansas Agricultural Experiment Station, Fayetteville, Ark, USA, 2014.

[73] K. Yagi and K. Minami, "Effect of organic matter application on methane emission from some Japanese paddy fields," Soil Science and Plant Nutrition, vol. 36, no. 4, pp. 599-610, 1990.

[74] K. F. Bronson, H.-U. Neue, U. Singh, and E. B. Abao Jr., "Automated chamber measurements of methane and nitrous oxide flux in a flooded rice soil: I. Residue, nitrogen, and water management," Soil Science Society of America Journal, vol. 61, no. 3, pp. 981-987, 1997.

[75] J. Ma, X. L. Li, H. Xu, Y. Han, Z. C. Cai, and K. Yagi, "Effects of nitrogen fertiliser and wheat straw application on $\mathrm{CH}_{4}$ and $\mathrm{N}_{2} \mathrm{O}$ emissions from a paddy rice field," Australian Journal of Soil Research, vol. 45, no. 5, pp. 359-367, 2007.

[76] R. J. Cicerone and J. D. Shetter, "Sources of atmospheric methane: measurements in rice paddies and a discussion," Journal of Geophysical Research, vol. 86, no. 8, pp. 7203-7209, 1981.

[77] R. Wassmann, H. U. Neue, R. S. Lantin et al., “Temporal patterns of methane emissions from wetland rice fields treated by different modes of $\mathrm{N}$ application," Journal of Geophysical Research, vol. 99, no. 8, pp. 16457-16462, 1994.

[78] W. W. Nazaroff, "Radon transport from soil to air," Reviews of Geophysics, vol. 30, no. 2, pp. 137-160, 1992.
[79] H. K. Kludze, R. D. DeLaune, and W. H. Patrick, "Aerenchyma formation and methane and oxygen exchange in rice," Soil Science Society of America Journal, vol. 57, no. 2, pp. 386-391, 1993. 

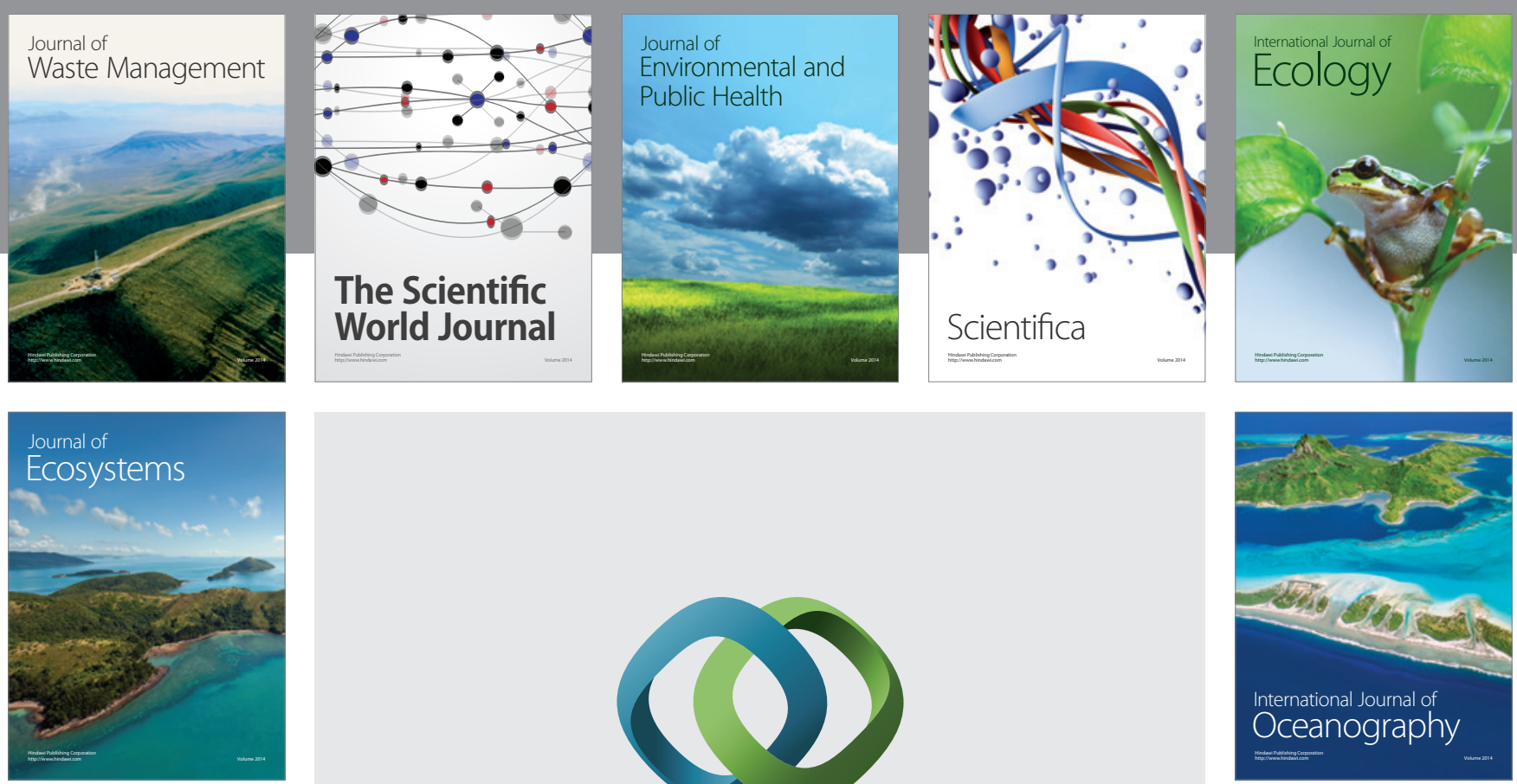

The Scientific World Journal
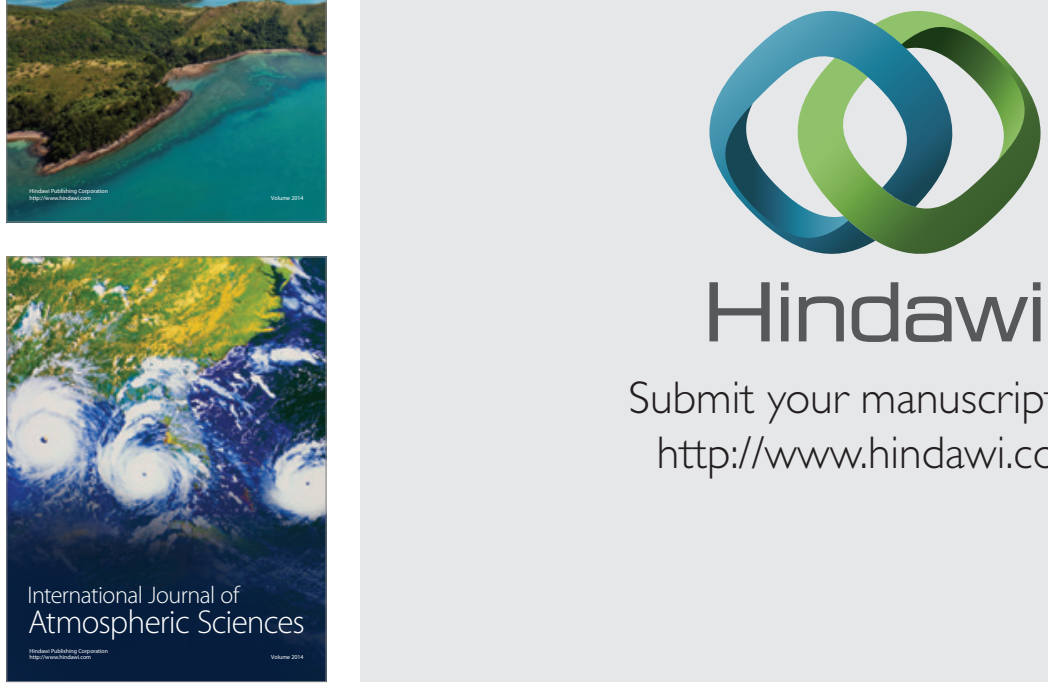

\section{Hindawi}

Submit your manuscripts at

http://www.hindawi.com
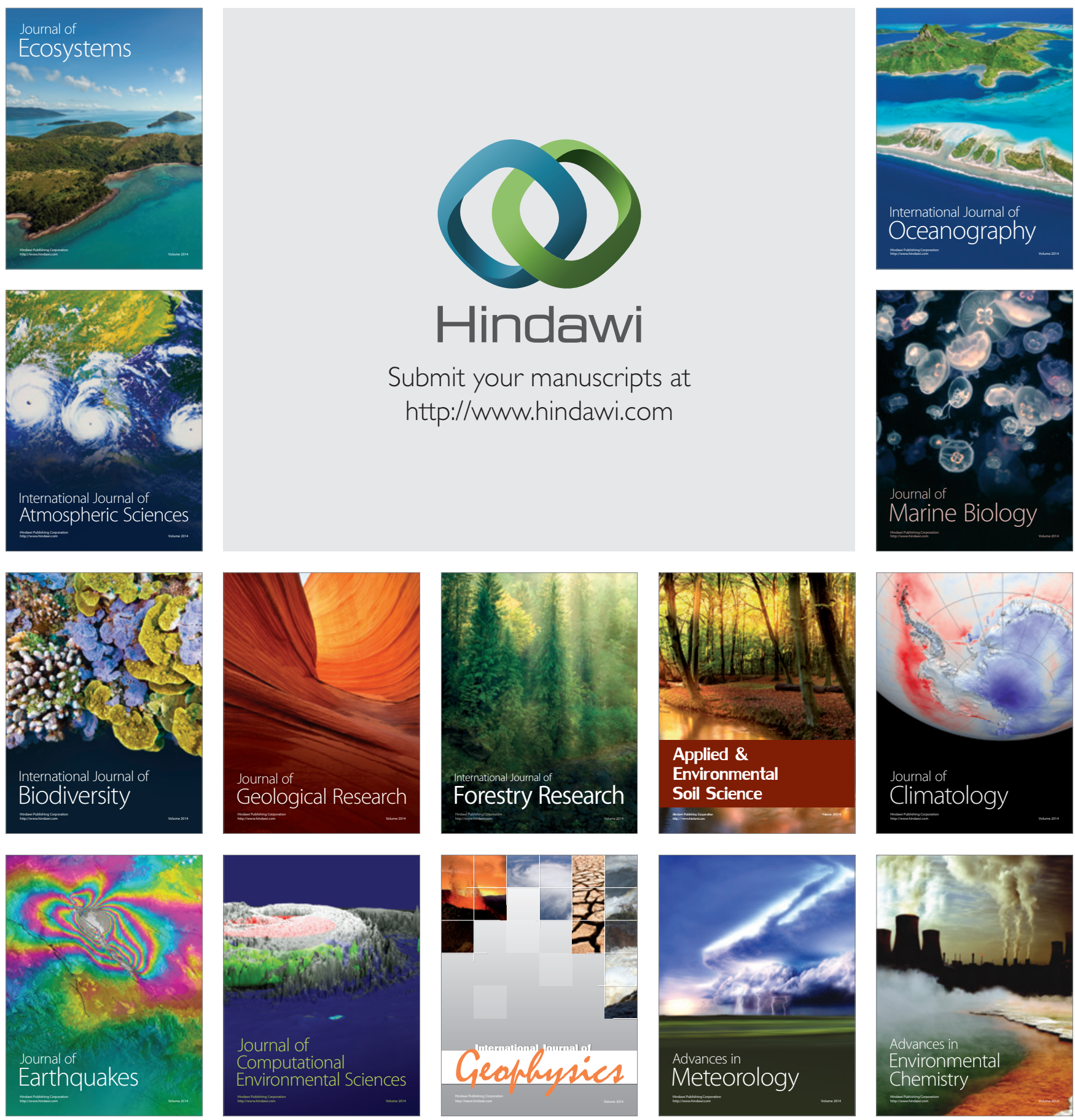